\title{
Stable Lewis Base Adducts of Tetrahalodiboranes: Synthetic Methods and Structural Diversity
}

\author{
Lukas Englert, ${ }^{[a]}$ Andreas Stoy, ${ }^{[a]}$ Merle Arrowsmith, ${ }^{[a]}$ Jonas H. Muessig, ${ }^{[a]}$ Melanie Thaler, ${ }^{[a]}$ Andrea \\ Deißenberger, ${ }^{[a]}$ Alena Häfner, ${ }^{[a]}$ Julian Böhnke, ${ }^{[a]}$ Florian Hupp, ${ }^{[a]}$ Jens Seufert, ${ }^{[a]}$ Jan Mies, ${ }^{[a]}$ \\ Alexander Damme, ${ }^{[a]}$ Theresa Dellermann, ${ }^{[a]}$ Kai Hammond, ${ }^{[a]}$ Thomas Kupfer, ${ }^{\left[{ }^{[a]}\right.}$ Krzysztof Radacki, ${ }^{[a]}$ \\ Torsten Thiess, ${ }^{[a]}$ Holger Braunschweig ${ }^{*,[a]}$
}

\begin{abstract}
A series of 22 new bis(phosphine), bis(carbene) and bis(isonitrile) tetrahalodiborane adducts has been synthesized, either by direct adduct formation with highly sensitive $B_{2} X_{4}$ precursors $(X=$ $\mathrm{Cl}, \mathrm{Br}, \mathrm{l})$ or by ligand exchange at stable $\mathrm{B}_{2} \mathrm{X}_{4}\left(\mathrm{SMe}_{2}\right)_{2}$ precursors $(X$ $=\mathrm{Cl}, \mathrm{Br}$ ) with labile dimethylsulfide ligands. The isolated compounds have been fully characterized using NMR spectroscopic, $(C, H, N)$ elemental and, for 20 of these compounds, X-ray crystallographic analysis, revealing an unexpected variation in the bonding motifs. Besides the classical $B_{2} X_{4} L_{2}$ diborane(6) adducts, some of the more sterically demanding carbene ligands induce a halide displacement leading to the first halide-bridged monocationic diboron species, $\left[B_{2} X_{3} L_{2}\right] A \quad\left(A=B C l_{4}, B r, l\right)$. Furthermore, low-temperature 1:1 reactions of $\mathrm{B}_{2} \mathrm{Cl}_{4}$ with sterically demanding $\mathrm{N}$-heterocyclic carbenes led to the formation of kinetically unstable mono-adducts, one of which was structurally characterized. A comparison of the NMR and structural data of new and literature-known bis-adducts shows several trends pertaining to the nature of the halides and the stereoelectronic properties of the Lewis bases employed.
\end{abstract}

\section{Introduction}

Diboron reagents enjoy a prominent position in organic chemistry where they are used in diboration and borylation reactions. ${ }^{[1]}$ In recent years singly base-stabilized $\mathrm{sp}^{2}-\mathrm{sp}^{3}$ diboranes(5) have received particular attention, as the polarization of their B-B bond generates an intrinsically nucleophilic boryl moiety, which can be used in uncatalyzed diborations or borylations. ${ }^{[2]}$ While the electrophilic nature of boron makes borylated organic molecules excellent crosscoupling partners, ${ }^{[3]}$ it is also the reason for the intrinsic instability of most diboron $(4)\left(B_{2} X_{4}\right)$ reagents, unless these are stabilized by strongly $\pi$-donating amino or alkoxy substituents, as is the case for all commercially available diboron(4) reagents. The chemistry of tetrahalodiboranes $\left(B_{2} X_{4}, X=\right.$ halide $)$ has been comparatively underexplored despite (and perhaps because of) their reactive $B-X$ bonds, which render both their synthesis and

[a] Institute for Inorganic Chemistry and the Institute for Sustainable Chemistry \& Catalysis with Boron, Julius-Maximilians-Universität Würzburg, Am Hubland, 97074 Würzburg, Germany. Email: h.braunschweig@uni-wuerzburg.de

Supporting information containing NMR and X-ray crystallographic data for this article can be found under:

CCDC 1904798 - 1904819 contain the supplementary crystallographic data for this paper. These data are provided free of charge by The Cambridge Crystallographic Data Centre.

storage challenging. First obtained in 1925 in poor yields from the reduction of $\mathrm{BCl}_{3}$ by a zinc arc discharge ${ }^{[4]} \mathrm{B}_{2} \mathrm{Cl}_{4}$ is a highly pyrophoric liquid that decomposes rapidly at $0{ }^{\circ} \mathrm{C}$. The optimization and scale-up of its synthesis by Schlesinger ${ }^{[5]}$ enabled its use as a precursor for the convenient solution phase syntheses of $\mathrm{B}_{2} \mathrm{~F}_{4},{ }^{[6]} \mathrm{B}_{2} \mathrm{Br}_{4}{ }^{[7]}$ and later $\mathrm{B}_{2} \mathrm{I}_{4}{ }^{[8]}$ by halogen exchange. Whereas $B_{2} F_{4}$ is stable up to moderately elevated temperatures, $\mathrm{B}_{2} \mathrm{Br}_{4}$ has to be stored below $-40{ }^{\circ} \mathrm{C}$ and $\mathrm{B}_{2} \mathrm{l}_{4}$ below $0{ }^{\circ} \mathrm{C}$ under the exclusion of light. An alternative multi-step synthesis of $\mathrm{B}_{2} \mathrm{Br}_{4}$ from commercially available $\mathrm{B}_{2}\left(\mathrm{NMe}_{2}\right)_{4}$ via $\mathrm{B}_{2}(\mathrm{OMe})_{4}$ was designed later by Nöth ${ }^{[9]}$ and recently provided the basis for the first solution phase synthesis of $\mathrm{B}_{2} \mathrm{Cl}_{4}$ by our group. ${ }^{[10]}$

\section{Synthesis and decomposition of unstable $B_{2} X_{4} L_{2}$ compounds}

a) $\begin{aligned} \mathrm{B}_{2} \mathrm{X}_{4} \underset{-78{ }^{\circ} \mathrm{C}}{\stackrel{2}{\stackrel{\mathrm{OEt}_{2}}{\longrightarrow}}} \mathrm{B}_{2} \mathrm{X}_{4}\left(\mathrm{OEt}_{2}\right)_{2} \underset{\frac{-\mathrm{OEt}_{2}}{\longrightarrow}}{\stackrel{\mathrm{T}}{\longrightarrow}} \mathrm{B}_{2} \mathrm{X}_{4}\left(\mathrm{OEt}_{2}\right) \underset{-\mathrm{XEt}}{\stackrel{\mathrm{T}}{\longrightarrow}} \text { decomposition } \\ \mathrm{X}=\mathrm{F}, \mathrm{T}=0^{\circ} \mathrm{C} \cdot \mathrm{X}=\mathrm{Cl}, \mathrm{T}=-23^{\circ} \mathrm{C}\end{aligned}$

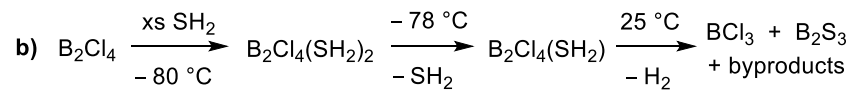

c) $\mathrm{B}_{2} \mathrm{Cl}_{4} \underset{25^{\circ} \mathrm{C}}{\stackrel{2 \mathrm{PH}_{3}}{\longrightarrow}} \mathrm{B}_{2} \mathrm{Cl}_{4}\left(\mathrm{PH}_{3}\right)_{2} \frac{65^{\circ} \mathrm{C}}{-\mathrm{PH}_{4} \mathrm{Cl}}$ decomposition

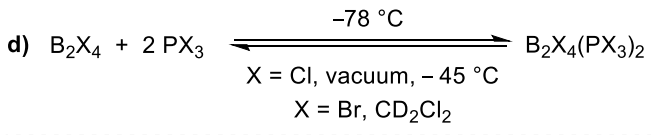

Synthesis of stable $B_{2} X_{4} L_{2}$ compounds

e) $\mathrm{B}_{2} \mathrm{Cl}_{4} \underset{-78{ }^{\circ} \mathrm{C}}{\stackrel{\mathrm{xs} \mathrm{NMe}}{\longrightarrow}} \mathrm{B}_{2} \mathrm{Cl}_{4}\left(\mathrm{NMe}_{3}\right)_{2} \stackrel{228{ }^{\circ} \mathrm{C}}{\longrightarrow} \begin{gathered}\text { melts without } \\ \text { decomposition }\end{gathered}$

f) $\mathrm{B}_{2}\left(\mathrm{NMe}_{2}\right)_{4} \frac{6 \mathrm{HCl}}{-78{ }^{\circ} \mathrm{C},-2\left[\mathrm{Me}_{2} \mathrm{NH}_{2}\right] \mathrm{Cl}} \mathrm{B}_{2} \mathrm{Cl}_{4}\left(\mathrm{NHMe}_{2}\right)_{2}$

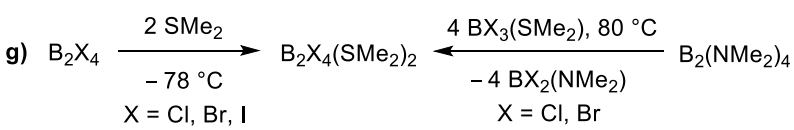

Scheme 1. Early syntheses of bis(base)-stabilized tetraholdiboranes(6)

With their two highly Lewis acidic boron atoms, tetrahalodiboranes(4) readily form adducts with neutral Lewis bases. While these are in general more electronically stable than their $\mathrm{B}_{2} \mathrm{X}_{4}$ precursors, the early days of this chemistry were marked by recurring problems of ligand lability and adduct decomposition. In diethyl ether at $-78{ }^{\circ} \mathrm{C}$, for example, $\mathrm{B}_{2} \mathrm{~F}_{4}$ and $\mathrm{B}_{2} \mathrm{Cl}_{4}$ form isolable bis-adducts with the solvent, which upon warming decompose to the mono(etherates), which in turn decompose by ether cleavage (Scheme 1a). ${ }^{\left[{ }^{[1,[6]}\right.}$ With $\mathrm{SH}_{2}$ and $\mathrm{PH}_{3}, \mathrm{~B}_{2} \mathrm{Cl}_{4}$ forms bis-adducts at $-78{ }^{\circ} \mathrm{C}$, which decompose upon 
warming, liberating $\mathrm{H}_{2}$ and $\mathrm{PH}_{4} \mathrm{Cl}$, respectively (Scheme 1b,c). ${ }^{[12]}$ With weaker phosphine donors, such as $\mathrm{PCl}_{3}$ and $\mathrm{PBr}_{3}$, adduct formation with $\mathrm{B}_{2} \mathrm{Cl}_{4}$ and $\mathrm{B}_{2} \mathrm{Br}_{4}$ was found to be reversible in solution (Scheme 1d). ${ }^{[13],[14]}$ In contrast, the monoadduct $\mathrm{B}_{2} \mathrm{Cl}_{4}\left(\mathrm{P}_{2} \mathrm{Me}_{4}\right)$ proved surprisingly stable, and upon addition of $\mathrm{NMe}_{3}$ yielded the first mixed-base diborane(6), $\mathrm{B}_{2} \mathrm{Cl}_{4}\left(\mathrm{P}_{2} \mathrm{Me}_{4}\right)\left(\mathrm{NMe}_{3}\right) .{ }^{[13]}$

With non-protic nitrogen donors, $\mathrm{B}_{2} \mathrm{~F}_{4}$ and $\mathrm{B}_{2} \mathrm{Cl}_{4}$ form stable mono- and bis-adducts, respectively. ${ }^{[11],[15]} \mathrm{B}_{2} \mathrm{Cl}_{4}\left(\mathrm{NMe}_{3}\right)_{2}$, in particular, remains stable up to its melting point at $228{ }^{\circ} \mathrm{C}$ and was crystallographically characterized as early as 1970 as displaying a centrosymmetric structure (B-B distance ca. $1.71 \AA$, Scheme 1e). ${ }^{[16]}$ While the reaction of protic $\mathrm{HNMe}_{2}$ with $\mathrm{B}_{2} \mathrm{Cl}_{4}$ results in hydrolysis of all four chloride ligands and formation of $\mathrm{B}_{2}\left(\mathrm{NMe}_{2}\right)_{4},{ }^{7]}$ the latter conversely reacts with 6 equivalents $\mathrm{HCl}$ to yield the stable bis(amine) adduct $\mathrm{B}_{2} \mathrm{Cl}_{4}\left(\mathrm{HNMe}_{2}\right)_{2}$ and two equivalents $\left[\mathrm{Me}_{2} \mathrm{NH}_{2}\right] \mathrm{Cl}$ as a byproduct (Scheme 1f). ${ }^{[17]}$ More recently, our group showed that stable dimethylsulfide bisadducts of all three heavier tetrahalodiboranes, $\mathrm{B}_{2} \mathrm{X}_{4}\left(\mathrm{SMe}_{2}\right)_{2}(\mathrm{X}$ $=\mathrm{Cl}, \mathrm{Br}, \mathrm{I})$, may be accessed by the traditional route of adding $\mathrm{SMe}_{2}$ to $\mathrm{B}_{2} \mathrm{X}_{4}$ at $-78{ }^{\circ} \mathrm{C}$, as well as by a high-yielding route from commercially available $\mathrm{B}_{2}\left(\mathrm{NMe}_{2}\right)_{4}$ by amine-halogen exchange with $\mathrm{BX}_{3}\left(\mathrm{SMe}_{2}\right)(\mathrm{X}=\mathrm{Cl}, \mathrm{Br})$ (Scheme 1g). ${ }^{[10]}$

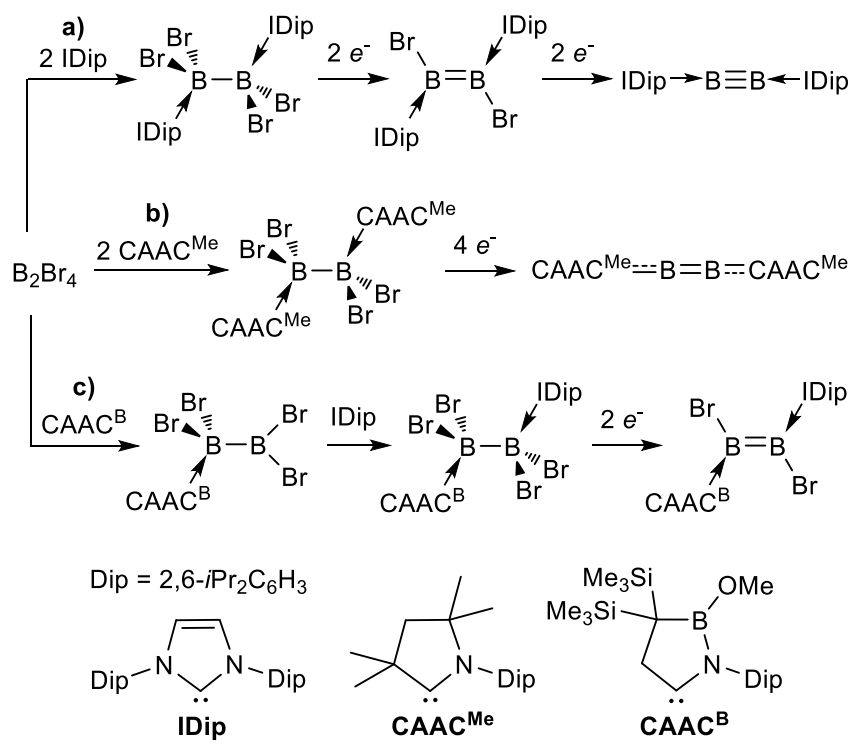

Scheme 2. Reduction of $\mathrm{B}_{2} \mathrm{Br}_{4} \mathrm{LL}$ ' to form compounds containing boron-boron multiple bonds.

Given the numerous synthetic challenges and stability issues exemplified in Scheme 1a-d, the first surge of interest in Lewis base tetrahalodiborane adducts died down in the early 1990s. It was renewed only recently in the wake of Robinson's landmark isolation of the first $\mathrm{N}$-heterocyclic carbene (NHC)-stabilized diborene, $\quad \mathrm{B}_{2} \mathrm{H}_{2}(\mathrm{IDip})_{2}$ (IDip = 1,3-bis(2,6-diisopropylphenyl)imidazole-2-ylidene), in which boron is in the formal oxidation state $+1 .{ }^{[18]}$ Following a computational study by Frenking and Jones on the suitability of $\mathrm{B}_{2} \mathrm{X}_{4}(\mathrm{IMe})_{2}$ adducts $(X=\mathrm{H}, \mathrm{Cl}$; IMe $=$ 1,3-dimethylimidazol-2-ylidene), as precursors for $\mathrm{B}_{2} \mathrm{X}_{2}(\mathrm{IMe})_{2}$ diborenes and the linear $\mathrm{B}_{2}(\mathrm{IMe})_{2}$ diboryne, ${ }^{[19]}$ our group showed that $\mathrm{B}_{2} \mathrm{Br}_{4}(\mathrm{IDip})_{2}$ could indeed be selectively reduced first to the corresponding diborene, $\mathrm{B}_{2} \mathrm{Br}_{2}(\text { IDip })_{2}$ and ultimately to the first isolable diboryne, $\mathrm{B}_{2}(\mathrm{IDip})_{2}$ (Scheme $\left.2 \mathrm{a}\right){ }^{[20]}$ Since then a handful of symmetrical low-valent diboron compounds have been synthesized by reduction of $\mathrm{B}_{2} \mathrm{Br}_{4} \mathrm{~L}_{2}$ precursors ( $\mathrm{L}=$ carbene), including a diboracumulene stabilized by strongly $\pi$-accepting cyclic (alkyl)(amino)carbene (CAAC) ligands (Scheme 2b). ${ }^{[21],[22]}$

More recently the group of Kinjo synthesized and structurally characterized the first mono-adduct of $\mathrm{B}_{2} \mathrm{Br}_{4}$ using a particularly $\pi$-acidic CAAC ligand displaying an endocyclic boron atom, $\mathrm{CAAC}^{\mathrm{B}}$ (Scheme 2c). ${ }^{[23]} \mathrm{B}_{2} \mathrm{Br}_{4}\left(\mathrm{CAAC}^{\mathrm{B}}\right)$ reacted with IDip (Scheme 2C) and $\mathrm{PMe}_{3}$ to yield the first unsymmetrical bisadducts of $\mathrm{B}_{2} \mathrm{Br}_{4}$, which were reduced to the corresponding diborene (Scheme $2 \mathrm{c}$ ) and a geminally bis $\left(\mathrm{PMe}_{3}\right)$-stabilized neutral allenic diborene, respectively. ${ }^{[23],[24]}$

In our quest to expand the scope and tune the sterics and electronics of low-valent diboron compounds our group has synthesized and characterized a number of stable tetrahalodiborane Lewis base adducts over the years. Herein we present an overview of the synthetic methods employed and compare the influence of various Lewis bases on the electronic and structural properties of these compounds.

\section{Results and Discussion}

\section{Synthesis and NMR characterization}

Following the traditional route, two equivalents of a Lewis base $L$ $(\mathrm{L}=$ phosphine, isonitrile, $\mathrm{NHC}$ or $\mathrm{CAAC})$ were added to a pentane or hexane solution of $\mathrm{B}_{2} \mathrm{Cl}_{4}$ or $\mathrm{B}_{2} \mathrm{Br}_{4}$ at $-78{ }^{\circ} \mathrm{C}$. For $\mathrm{B}_{2} \mathrm{I}_{4}$ the reagents were simply combined in benzene at room temperature. The reaction mixtures were stirred for 1 to 2 hours at room temperature, prior to isolation of the colorless precipitates by filtration, washing with pentane or hexane and drying in vacuo. The resulting $\mathrm{B}_{2} \mathrm{X}_{4} \mathrm{~L}_{2}$ bis-adducts were obtained in moderate to excellent yields ( 47 to $92 \%$, Scheme 3 ).

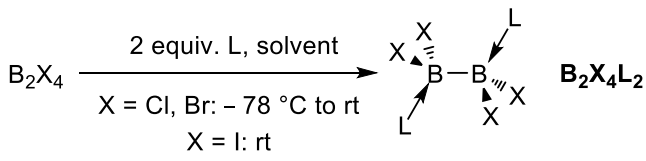

$$
\begin{aligned}
& X=\mathrm{Cl}, \quad \mathrm{L}=\mathrm{CN} t \mathrm{Bu}, \mathrm{liPr} \text {, IDipiPr, IMes, CAAC }{ }^{\mathrm{Me}} \\
& X=B r, \quad L=\mathrm{PMe}_{3}, \mathrm{PiPr}_{3}, \mathrm{PCy}_{3}, \mathrm{CNDip}, \mathrm{IDip} i \mathrm{Pr} \text {, IDep } \\
& X=I, \quad L=C N t B u
\end{aligned}
$$

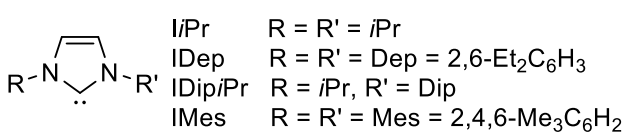

Scheme 3. Synthesis of $B_{2} X_{4} L_{2}$ bis-adducts from $B_{2} X_{4}$ and monodentate Lewis bases.

The solubility of these tetrahalodiborane(6) compounds in benzene increases from virtually insoluble in the case of the chloro-derivatives to fully soluble in the case of the iododerivative. The solid-state structures of all eleven compounds were confirmed by X-ray crystallographic analysis (vide infra). 

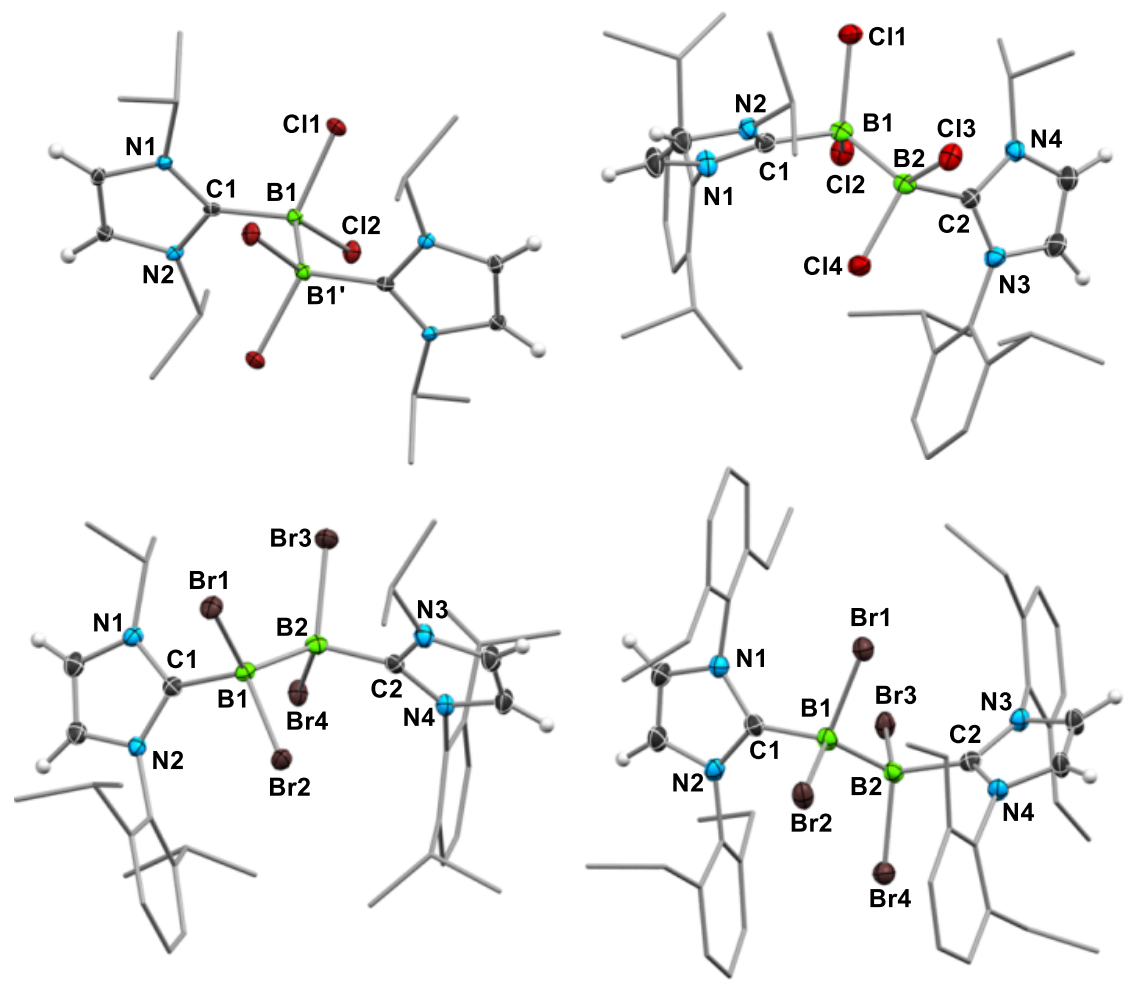
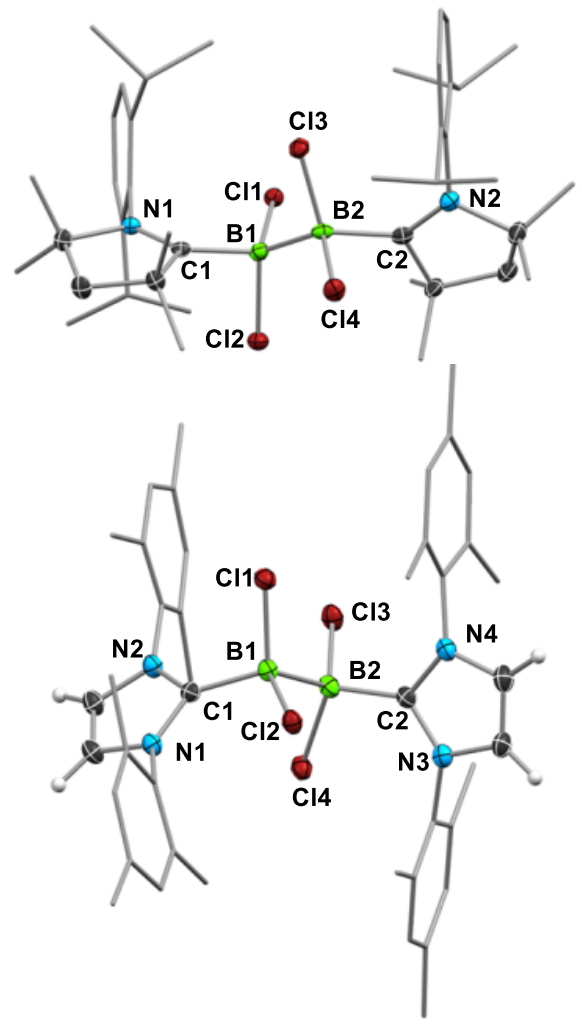

Figure 1. Crystallographically-derived molecular structures of the bis-carbene adducts (from left to right, top) $\mathrm{B}_{2} \mathrm{Cl}_{4}\left(\mathrm{IIPr}_{2}, \mathrm{~B}_{2} \mathrm{Cl}_{4}(\mathrm{IDip} i \mathrm{Pr})_{2}, \mathrm{~B}_{2} \mathrm{Cl}_{4}\left(\mathrm{CAAC} \mathrm{Me}_{2},(\right.\right.$ from left to right, bottom) $\mathrm{B}_{2} \mathrm{Br}_{4}(\mathrm{IDipiPr})_{2}, \mathrm{~B}_{2} \mathrm{Br}_{4}(\mathrm{IDep})_{2}$ and $\mathrm{B}_{2} \mathrm{Cl}_{4}(\mathrm{IMes})_{2}$. Thermal ellipsoids drawn at $50 \%$ probability level. Ellipsoids on the ligand peripheries and most hydrogen atoms omitted for clarity.

While the majority of these compounds can be stored indefinitely at room temperature under an argon atmosphere and are stable in chlorinated solvents, $\mathrm{B}_{2} \mathrm{Cl}_{4}(\mathrm{I} i \mathrm{Pr})_{2}$ and $\mathrm{B}_{2} \mathrm{Cl}_{4}(\mathrm{IDip} i \mathrm{Pr})_{2}(\mathrm{I} i \mathrm{Pr}=$ 1,3-diisopropylimidazol-2-ylidene; $\quad \mathrm{IDipiPr}=1-(2,6-$ diisopropylphenyl)-3-isopropylimidazol-2-ylidene) decomposed under these conditions to the imidazolium hydrochloride salts and a number of unidentified boron species. Furthermore, isolated $\mathrm{B}_{2} \mathrm{Cl}_{4}(\mathrm{CN} t \mathrm{Bu})_{2}$ was found to decompose in $\mathrm{C}_{6} \mathrm{D}_{6}$ and $\mathrm{CD}_{2} \mathrm{Cl}_{2}$ over a period of several days at room temperature into a multitude of unidentifiable boron-containing species (see Fig. S5 in the SI). While a wide variety of decomposition pathways of CNtBu-stabilized diboron compounds has been reported, including insertion into the B-B bond, C-C-coupling, CEN cleavage and isoprene elimination, ${ }^{[25]}$ it is noteworthy that the heavier homologues, $\mathrm{B}_{2} \mathrm{Br}_{4}(\mathrm{CNtBu})_{2}$ and $\mathrm{B}_{2} \mathrm{l}_{4}(\mathrm{CNtBu})_{2}$, are indefinitely stable in solution.

A comparison of the ${ }^{11} \mathrm{~B}$ NMR resonances of analogous tetrachloro, -bromo and -iodo $\mathrm{B}_{2} \mathrm{X}_{4} \mathrm{~L}_{2}$ derivatives, both new and literature-known, shows increasing upfield shifts down the group (Table 1). $\mathrm{B}_{2} \mathrm{I}_{4}(\mathrm{CN} t \mathrm{Bu})_{2}$, for example, displays an ${ }^{11} \mathrm{~B}$ NMR shift of $-43.1 \mathrm{ppm}$, ca. $27 \mathrm{ppm}$ upfield of $\mathrm{B}_{2} \mathrm{Br}_{4}(\mathrm{CNtBu})_{2}$ at -16.5 ppm. ${ }^{[25] c} A$ comparably large shift difference of 20 to $24 \mathrm{ppm}$ is observed for $\mathrm{B}_{2} \mathrm{l}_{4}\left(\mathrm{SMe}_{2}\right)_{2}\left(\delta_{11 \mathrm{~B}}=-20.0 \mathrm{ppm}\right)$ and $\mathrm{B}_{2} \mathrm{Br}_{4}\left(\mathrm{SMe}_{2}\right)_{2}$ $\left(\delta_{11 \mathrm{~B}}=-0.3 \mathrm{ppm}\right),{ }^{[10]}$ as well as $\mathrm{B}_{2} \mathrm{I}_{4}\left(\mathrm{PCy}_{3}\right)_{2}\left(\delta_{11 \mathrm{~B}}=-28.0 \mathrm{ppm}\right)$

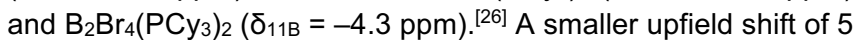
to $8 \mathrm{ppm}$ is observed between pairs of $\mathrm{B}_{2} \mathrm{Cl}_{4} \mathrm{~L}_{2}$ and $\mathrm{B}_{2} \mathrm{Br}_{4} \mathrm{~L}_{2}$ analogues, e.g. for $\mathrm{B}_{2} \mathrm{Cl}_{4}\left(\mathrm{SMe}_{2}\right)_{2} \quad\left(\delta_{11 \mathrm{~B}}=7.3 \mathrm{ppm}\right)$ and $\mathrm{B}_{2} \mathrm{Br}_{4}\left(\mathrm{SMe}_{2}\right)_{2} \quad\left(\delta_{11 \mathrm{~B}}=-0.3 \mathrm{ppm}\right),{ }^{[10]} \mathrm{B}_{2} \mathrm{Cl}_{4}\left(\mathrm{PMe}_{3}\right)_{2} \quad\left(\delta_{11 \mathrm{~B}}=0.3\right.$ $\mathrm{ppm})^{[27]}$ and $\mathrm{B}_{2} \mathrm{Br}_{4}\left(\mathrm{PMe}_{3}\right)_{2}\left(\delta_{11 \mathrm{~B}}=-7.3 \mathrm{ppm}\right)$ and $\mathrm{B}_{2} \mathrm{Cl}_{4}\left(\mathrm{CAAC}^{\mathrm{Me}}\right)_{2}$ $\left(\delta_{11 \mathrm{~B}}=2.3 \mathrm{ppm}\right)$ and $\mathrm{B}_{2} \mathrm{Br}_{4}\left(\mathrm{CAAC}^{\mathrm{Me}}\right)_{2}\left(\delta_{11 \mathrm{~B}}=-2.3 \mathrm{ppm}\right){ }^{[21]}$ This is in line with the greater increase in relative electronegativity from I to $\mathrm{Br}$ (ca. 11\%) than from $\mathrm{Br}$ to $\mathrm{Cl}$ (ca. $7 \%$ ). ${ }^{[28]}$ For a given halogen the ${ }^{11} B$ NMR shifts of $B_{2} X_{4} L_{2}$ derivatives are particularly sensitive to the overall electron donor strength of the ligands. $A$ comparison of the compounds shown in Scheme 1 with literature data provides the following order of overall electron donor strength: $\mathrm{SMe}_{2}<$ IDep $<$ CAACMe $<$ IDip $<\mathrm{PCy}_{3}<\mathrm{PiPr}_{3}<\mathrm{PMe}_{3}$ $<$ CNDip $<$ CNtBu (Table 1).

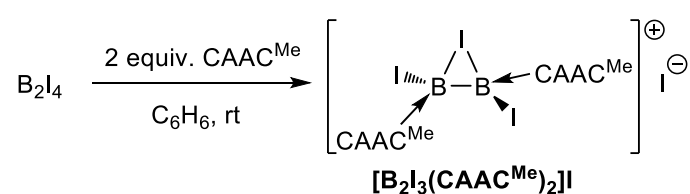

Scheme 4. Formation of ionic, iodide-bridged $\left[\mathrm{B}_{2} \mathrm{l}_{3}\left(\mathrm{CAAC}{ }^{\mathrm{Me}}\right)_{2}\right] \mathrm{l}$.

For the adduct formation of $\mathrm{B}_{2} \mathrm{l}_{4}$ with $\mathrm{CAAC}^{\mathrm{Me}}$ an ionic species, $\left[\mathrm{B}_{2} \mathrm{I}_{3}\left(\mathrm{CAAC}{ }^{\mathrm{Me}}\right)_{2}\right] \mathrm{l}$, was obtained by displacement of one of the iodides. The compound displays a single, very broad ${ }^{11} \mathrm{~B}$ NMR $B_{2}$ resonance at $-5.9 \mathrm{ppm}$, significantly downfield from that expected for a classical $\mathrm{B}_{2} \mathrm{I}_{4}\left(\mathrm{CAAC}^{\mathrm{Me}}\right)_{2}$ diborane(6) bis-adduct, which would appear slightly downfield of that of $\mathrm{B}_{2} \mathrm{I}_{4}\left(\mathrm{PCy}_{3}\right)_{2}$ at $28 \mathrm{ppm}$. The solid-state structure of $\left[\mathrm{B}_{2} \mathrm{l}_{3}\left(\mathrm{CAAC} \mathrm{Me}_{2}\right)_{2}\right]$ shows that one of the iodide ligands of the diboron cation occupies a bridging position (vide infra). It is the first example of such a structural motif for Lewis base-stabilized tetrahalodiboranes. 
Table 1. ${ }^{11} \mathrm{~B}$ NMR and $\mathrm{X}$-ray crystallographic data for a selection of literature-known and new Lewis base adducts of $\mathrm{B}_{2} \mathrm{X} \mathrm{X}_{4} \mathrm{X}=\mathrm{Cl}, \mathrm{Br}, \mathrm{I}$

\begin{tabular}{|c|c|c|c|c|c|c|c|}
\hline \multirow{2}{*}{$\begin{array}{l}\text { Compound } \\
\text { type }\end{array}$} & \multirow[t]{2}{*}{ Formula } & \multirow{2}{*}{$\begin{array}{l}{ }^{11} \text { B NMR } \\
\text { shifts (ppm) [a] }\end{array}$} & \multicolumn{3}{|l|}{ Bond lengths $(\AA)$} & \multirow{2}{*}{$\begin{array}{l}\text { Torsion angle } \\
(\mathrm{L}, \mathrm{B}, \mathrm{B}, \mathrm{L})\left(^{\circ}\right)\end{array}$} & \multirow[t]{2}{*}{ Ref. } \\
\hline & & & B-B & $B-X$ & $B-E_{L}$ & & \\
\hline \multirow[t]{3}{*}{$\mathrm{B}_{2} \mathrm{X}_{4} \mathrm{~L}$} & $\mathrm{~B}_{2} \mathrm{Cl}_{4}(\mathrm{IMes})$ & $68.5,-4.6$ & $1.719(4)$ & $\begin{array}{l}\mathrm{sp}^{2}-\mathrm{B} 1.882(3), 1.893(3) \\
\mathrm{sp}^{3}-\mathrm{B} 1.753(3), 1.764(4)\end{array}$ & $1.619(4)$ & - & [f] \\
\hline & $\mathrm{B}_{2} \mathrm{Cl}_{4}(\mathrm{IDip})$ & $68.7,-4.1$ & - & - & - & - & [f] \\
\hline & $\mathrm{B}_{2} \mathrm{Br}_{4}\left(\mathrm{CAAC}^{\mathrm{B}}\right)$ & $67.3,-6.3$ & $1.72(2)$ & $\begin{array}{l}\mathrm{sp}^{2}-\mathrm{B} 2.03(1), 2.058(9) \\
\mathrm{sp}^{3}-\mathrm{B} 1.89(1), 1.910(8)\end{array}$ & $1.61(1)$ & - & [23] \\
\hline \multirow[t]{29}{*}{$\mathrm{B}_{2} \mathrm{X}_{4} \mathrm{~L}_{2}$} & $\mathrm{~B}_{2} \mathrm{Cl}_{4}\left(\mathrm{SMe}_{2}\right)_{2}$ & 7.3 & $1.719(2)$ & $1.861(1), 1.868(1)$ & $1.976(1)$ & 180 & [10] \\
\hline & $\mathrm{B}_{2} \mathrm{Cl}_{4}\left(\mathrm{PMe}_{3}\right)_{2}$ & 0.3 & $1.718(3)$ & $1.900(1)$ & $1.9626(13)$ & 180 & {$[27]$} \\
\hline & $\mathrm{B}_{2} \mathrm{Cl}_{4}\left(\mathrm{PCy}_{3}\right)_{2}$ & 4.8 & $1.735(8)$ & $1.884(6)-1.907(5)$ & $2.035(5)$ & $162.2(3)$ & [f] \\
\hline & $\mathrm{B}_{2} \mathrm{Cl}_{4}(\mathrm{liPr})_{2}$ & 3.5 & $1.754(6)$ & $1.910(3), 1.915(3)$ & $1.633(4)$ & 180 & [f] \\
\hline & $\mathrm{B}_{2} \mathrm{Cl}_{4}(\mathrm{IDip} i \mathrm{Pr})_{2}$ & 2.4 & $1.757(4)$ & $1.886(3)-1.925(3)$ & $1.640(3), 1.641(3)$ & $154.1(2)$ & [f] \\
\hline & $\mathrm{B}_{2} \mathrm{Cl}_{4}(\mathrm{IMes})_{2}$ & 2.7 & $1.760(4)$ & $1.874(3)-1.912(3)$ & $1.645(3), 1.646(3)$ & $154.7(2)$ & [f] \\
\hline & $\mathrm{B}_{2} \mathrm{Cl}_{4}(\mathrm{SIMes})_{2}$ & 1.1 & - & - & - & - & [f] \\
\hline & $\mathrm{B}_{2} \mathrm{Cl}_{4}\left(\mathrm{CAAC}^{\mathrm{Me}}\right)_{2}{ }^{[\mathrm{b}]}$ & 2.6 & $1.758(5), 1.763(3)$ & $1.878(3)-1.941(2)$ & $1.668(3)-1.683(4)$ & $178.1(2), 179.0(2)$ & [f] \\
\hline & $\mathrm{B}_{2} \mathrm{Br}_{4}\left(\mathrm{SMe}_{2}\right)_{2}$ & -0.3 & $1.715(4)$ & 2.026(2), $2.051(2)$ & $1.961(2)$ & 180 & [10] \\
\hline & $\mathrm{B}_{2} \mathrm{Br}_{4}\left(\mathrm{PMe}_{3}\right)_{2}$ & -7.3 & $1.713(4)$ & 2.059(2), $2.068(2)$ & $1.956(2)$ & 180 & [f] \\
\hline & $\mathrm{B}_{2} \mathrm{Br}_{4}\left(\mathrm{PEt}_{3}\right)_{2}$ & -6.7 & $1.708(7)$ & $2.061(5)-2.071(5)$ & $1.974(5), 1.977(5)$ & $170.3(2)$ & [f] \\
\hline & $\mathrm{B}_{2} \mathrm{Br}_{4}\left(\mathrm{PiPr}_{3}\right)_{2}$ & -5.2 & $1.748(3)$ & $2.064(3)-2.081(3)$ & $2.033(3), 2.050(3)$ & 167.1(1) & [f] \\
\hline & $\mathrm{B}_{2} \mathrm{Br}_{4}\left(\mathrm{PCy}_{3}\right)_{2}$ & -4.3 & $1.746(7)$ & $2.052(4)-2.073(5)$ & $2.019(5), 2.026(5)$ & $163.1(2)$ & [26] \\
\hline & $\mathrm{B}_{2} \mathrm{Br}_{4}\left(\mathrm{Me}_{2} \mathrm{Ph}\right)_{2}$ & -6.8 & $1.718(5)$ & 2.069(2), $2.054(3)$ & $1.975(3)$ & 180 & [f] \\
\hline & $\mathrm{B}_{2} \mathrm{Br}_{4}(\mathrm{dppf})$ & -5.0 & $1.752(6)$ & $2.051(4)-2.064(5)$ & $2.006(4), 2.018(4)$ & $50.5(5)$ & [f] \\
\hline & $\mathrm{B}_{2} \mathrm{Br}_{4}\left(\mathrm{dppa} \mathrm{a}^{\mathrm{iPr}}\right)$ & -6.7 & $1.714(7)$ & $2.027(5)-2.042(5)$ & $1.980(5), 1.995(5)$ & $32.7(3)$ & [f] \\
\hline & $\mathrm{B}_{2} \mathrm{Br}_{4}\left(\mathrm{dppa}^{\mathrm{Mes}}\right)$ & -7.0 & - & - & - & - & [f] \\
\hline & $\mathrm{B}_{2} \mathrm{Br}_{4}\left(\mathrm{dppa}^{\mathrm{PhF}}\right)$ & -7.2 & $1.713(3)$ & 2.058(2), 2.068(2) & $1.956(2)$ & $22.6(1)$ & [f] \\
\hline & $\mathrm{B}_{2} \mathrm{Br}_{4}(\mathrm{CN} t \mathrm{Bu})_{2}$ & -16.5 & $1.716(5)$ & $2.027(4)-2.034(4)$ & $1.570(5), 1.592(5)$ & $177.7(3)$ & {$[25] \mathrm{c}$} \\
\hline & $\mathrm{B}_{2} \mathrm{Br}_{4}(\mathrm{CNDip})_{2}$ & -15.7 & $1.732(3)$ & $2.016(3)-2.044(2)$ & $1.581(4), 1.579(4)$ & $172.9(2)$ & [f] \\
\hline & $\mathrm{B}_{2} \mathrm{Br}_{4}(\mathrm{IDip} i \mathrm{Pr})_{2}$ & -2.2 & $1.764(4)$ & $2.048(3)-2.116(3)$ & $1.637(3), 1.638(3)$ & $151.4(2)$ & [f] \\
\hline & $\mathrm{B}_{2} \mathrm{Br}_{4}(\mathrm{IDep})_{2}$ & $0.8^{[29]}$ & $1.736(6)^{[f]}$ & $2.053(4)-2.086(4)^{[f]}$ & $1.663(5), 1.664(5)^{[f]}$ & $159.3(3)^{[f]}$ & [29],ff] \\
\hline & $\mathrm{B}_{2} \mathrm{Br}_{4}(\mathrm{IDip})_{2}$ & -4.8 & - & - & - & - & [20] \\
\hline & $\mathrm{B}_{2} \mathrm{Br}_{4}\left(\mathrm{CAAC}^{\mathrm{Me}}\right)_{2}$ & -2.3 & $1.754(5)$ & $2.058(3)-2.136(3)$ & $1.660(4), 1.667(4)$ & $177.3(3)$ & [21] \\
\hline & $\mathrm{B}_{2} \mathrm{l}_{4}\left(\mathrm{SMe}_{2}\right)_{2}$ & -20.0 & $1.714(7)$ & $2.250(3), 2.280(3)$ & $1.955(4)$ & 180 & {$[10]$} \\
\hline & $\mathrm{B}_{2} \mathrm{I}_{4}\left(\mathrm{PMe}_{3}\right)_{2}$ & -27 & $1.727(7)$ & $2.290(5), 2.298(5)$ & $1.958(5)$ & 180 & [26] \\
\hline & $\mathrm{B}_{2} \mathrm{l}_{4}\left(\mathrm{PCy}_{3}\right)_{2}$ & -28 & $1.766(6)$ & $2.293(4)-2.313(4)$ & $2.013(4), 2.027(4)$ & $163.1(2)$ & {$[26]$} \\
\hline & $\mathrm{B}_{2} \mathrm{I}_{4}\left(\mathrm{P}\left(\mathrm{CH}_{2} \mathrm{Cy}\right)_{3}\right)_{2}$ & -26 & $1.759(5)$ & $2.281(3)-2.306(3)$ & $1.980(4), 1.981(4)$ & $167.2(2)$ & [26] \\
\hline & $\mathrm{B}_{2} \mathrm{l}_{4}(\mathrm{CNtBu})_{2}$ & -43.1 & $1.675(16)$ & 2.259(8), 2.287(8) & $1.560(10)$ & 180 & [f] \\
\hline \multirow[t]{4}{*}[B_{2}X_{3}L_{2}]{$A$} & {$\left[\mathrm{~B}_{2} \mathrm{Cl}_{3}(\mathrm{IMes})_{2}\right]\left[\mathrm{BCl}_{4}\right]$} & $13.6(\mathrm{br}), 6.9$ & $1.667(3)$ & $\begin{array}{l}B-X_{t} 1.816(3), 1.823(3)^{[c]} \\
B-X_{b} 2.033(2), 2.078(3)\end{array}$ & $1.610(3), 1.611(3)$ & 163.1(2) & [f] \\
\hline & {$\left[\mathrm{B}_{2} \mathrm{Cl}_{3}(\mathrm{IDip})_{2}\right]\left[\left.\mathrm{BC}\right|_{4}\right]$} & $36.6(\mathrm{br}), 6.9$ & $-[d]$ & $-[d]$ & $-[d]$ & $-[d]$ & [f] \\
\hline & {$\left[\mathrm{B}_{2} \mathrm{Br}_{3}\left(\mathrm{CAAC}{ }^{\mathrm{Me}}\right)_{2}\right] \mathrm{Br}$} & $7.8(\mathrm{br})$ & $-[d]$ & $-[d]$ & $-[d]$ & $-[d]$ & [f] \\
\hline & {$\left[\mathrm{B}_{2} \mathrm{I}_{3}\left(\mathrm{CAAC}{ }^{\mathrm{Me}}\right)_{2}\right] \mathrm{I}$} & -5.9 & $1.677(8)$ & $\begin{array}{l}\mathrm{B}-\mathrm{X}_{\mathrm{t}} 2.258(5), 2.259(5)^{[\mathrm{e}]} \\
\mathrm{B}-\mathrm{X}_{\mathrm{b}} 2.400(5), 2.422(5)\end{array}$ & $1.584(7), 1.590(7)$ & $138.3(6)$ & [f] \\
\hline \multirow[t]{2}{*}{$\mathrm{B}_{2} \mathrm{X}_{4} \mathrm{LL}^{\prime}$} & $\left.\mathrm{B}_{2} \mathrm{Br}_{4}(\mathrm{IDip})(\mathrm{CAAC})^{\mathrm{B}}\right)^{[\mathrm{f}]}$ & $-3.8(\mathrm{br})$ & $1.734(6), 1.735(6)$ & $2.048(4)-2.101(4)$ & $\begin{array}{l}\text { B-C } \mathrm{C}_{\mathrm{NHC}} 1.642(6), 1.641(6) \\
\mathrm{B}-\mathrm{C}_{\mathrm{CAAC}} 1.622(5), 1.626(5)\end{array}$ & 169.7(3), 171.1(3) & [23] \\
\hline & $\mathrm{B}_{2} \mathrm{Br}_{4}\left(\mathrm{PMe}_{3}\right)\left(\mathrm{CAAC}^{\mathrm{B}}\right)$ & $43.2,-4.8$ & $1.734(3)$ & $2.059(2)-2.084(2)$ & B-P 1.962(2), B-C 1.617(3) & $166.3(1)$ & [24] \\
\hline
\end{tabular}

[a] At $25^{\circ} \mathrm{C}$; [b] structural data for both hexane and toluene co-crystals; [c] $X_{t}=$ terminal $X, X_{b}=$ bridging $X$; [d] disorder preventing discussion of structural parameters; [e] two molecules present in the asymmetric unit; [f] this work. 


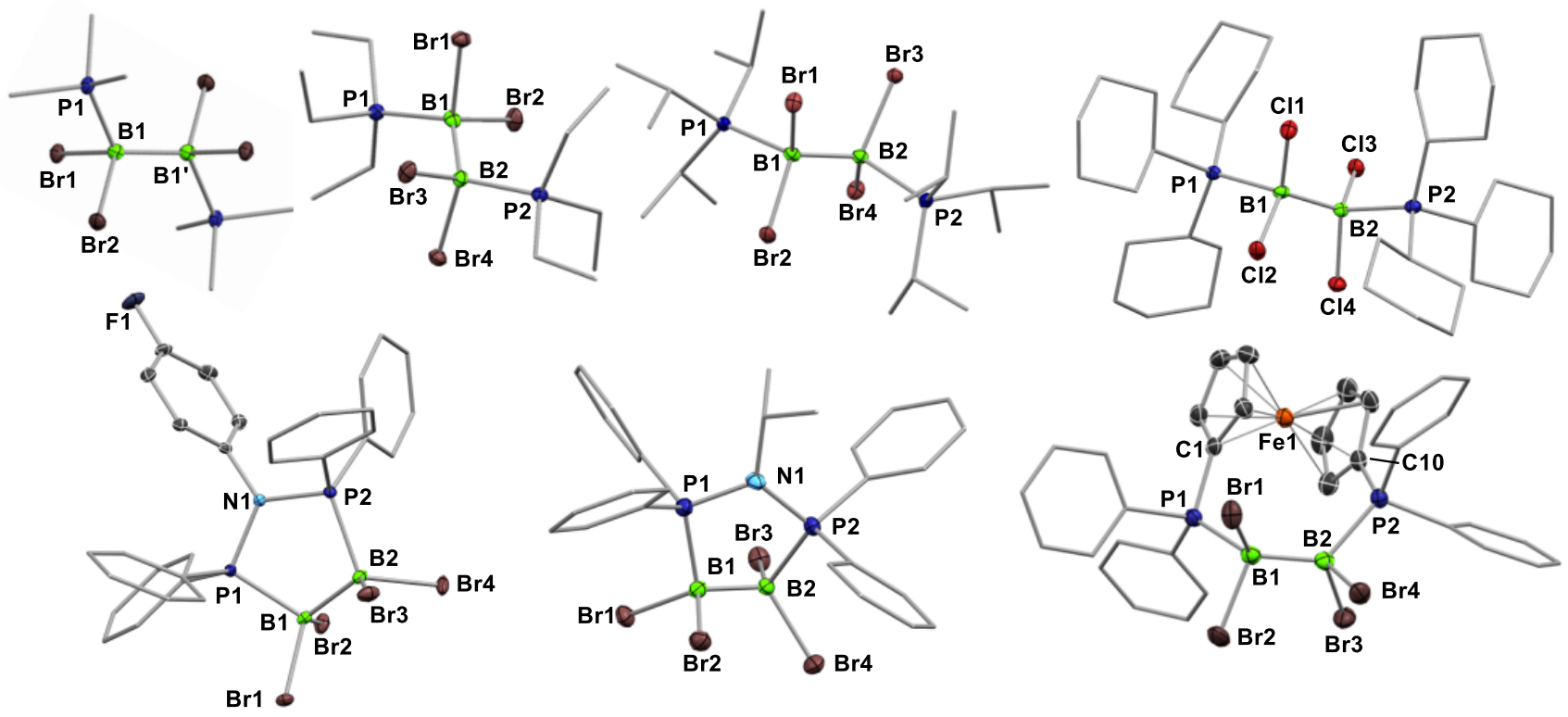

Figure 2. Crystallographically-derived molecular structures of (from left to right, top) $\mathrm{B}_{2} \mathrm{Br}_{4}\left(\mathrm{PMe}_{3}\right)_{2}, \mathrm{~B}_{2} \mathrm{Br}_{4}\left(\mathrm{PEt}_{3}\right)_{2}, \mathrm{~B}_{2} \mathrm{Br}_{4}\left(\mathrm{PiPr}_{3}\right)_{2}, \mathrm{~B}_{2} \mathrm{Cl}_{4}\left(\mathrm{PCy}_{3}\right)_{2},($ from left to right, bottom), $\mathrm{B}_{2} \mathrm{Br}_{4}\left(\mathrm{dppa}{ }^{\mathrm{PhF}}\right), \mathrm{B}_{2} \mathrm{Br}_{4}\left(\mathrm{dppa} \mathrm{a}^{\mathrm{Pr}}\right)$ and $\mathrm{B}_{2} \mathrm{Br}_{4}(\mathrm{dppf})$. Thermal ellipsoids drawn at $50 \%$ probability level. Ellipsoids on the ligand peripheries and hydrogen atoms omitted for clarity.

Furthermore, the reaction of IMes and IDip with one equivalent of $\mathrm{B}_{2} \mathrm{Cl}_{4}$ at $-78{ }^{\circ} \mathrm{C}$ led to the formation of the mono-adducts $\mathrm{B}_{2} \mathrm{Cl}_{4}$ (IMes) and $\mathrm{B}_{2} \mathrm{Cl}_{4}$ (IDip), respectively, as well as small amounts of the corresponding $\mathrm{B}_{2} \mathrm{Cl}_{4}(\mathrm{NHC})_{2}$ bis-adducts (Scheme 5). These highly unstable compounds were identified by low-temperature ${ }^{11} \mathrm{~B}$ NMR spectroscopy by their two major broad resonances around -69 and -5 ppm, alongside several minor side products. These resonances are similar to those observed for the only other reported $\mathrm{B}_{2} \mathrm{Cl}_{4}$ mono-adduct,

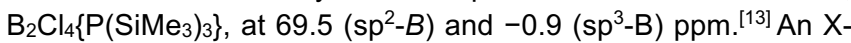
ray crystallographic experiment on single crystals of $\mathrm{B}_{2} \mathrm{Cl}_{4}$ (IMes) obtained by diffusion of pentane into a saturated odifluorobenzene solution at $-30{ }^{\circ} \mathrm{C}$ confirmed the formation of the $1: 1$ adduct (vide infra).

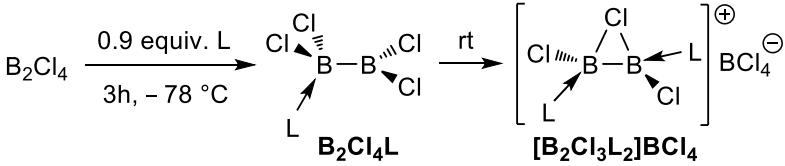

$$
\begin{aligned}
& \text { + small amounts } \quad \mathrm{L}=\text { IMes, IDip } \\
& \text { of } \mathrm{B}_{2} \mathrm{Cl}_{4} \mathrm{~L}_{2}
\end{aligned}
$$

Scheme 5. Low-temperature formation of $\mathrm{a}_{2} \mathrm{Cl}_{4}$ mono-NHC adducts.

Warming of these reaction mixtures to room temperature resulted in decomposition into the ionic, chloride-bridged compounds $\left[\mathrm{B}_{2} \mathrm{Cl}_{3}(\mathrm{IMes})_{2}\right]\left[\mathrm{BCl}_{4}\right]$ and $\left[\mathrm{B}_{2} \mathrm{Cl}_{3}(\mathrm{IDip})_{2}\right]\left[\mathrm{BCl}_{4}\right]$, respectively, both structurally confirmed by $\mathrm{X}$-ray crystallographic analysis (vide infra). Both compounds display a sharp ${ }^{11} \mathrm{~B}$ NMR singlet at $6.9 \mathrm{ppm}$ for the $\mathrm{BCl}_{4}^{-}$counteranion, which is likely formed by the addition of the expelled chloride anion to free $\mathrm{BCl}_{3}$, resulting from the inevitable disproportionation of excess $\mathrm{B}_{2} \mathrm{Cl}_{4}$ upon warming the reaction mixture to room temperature. The broad ${ }^{11} \mathrm{~B}$ NMR $B_{2}$ resonances of the $\left[\mathrm{B}_{2} \mathrm{Cl}_{3}(\mathrm{NHC})_{2}\right]$ cations (13.6 and $36.6 \mathrm{ppm}$ for $\mathrm{NHC}=$ IMes and IDip, respectively) are downfield-shifted from those of their $\mathrm{B}_{2} \mathrm{Cl}_{3}(\mathrm{NHC})_{2}$ diborane(6) counterparts (2.7 and 1.5 ppm, respectively). The surprisingly low-field ${ }^{11} B$ NMR shift of the IDip- versus the IMes-analogue may be caused by reversible ligand dissociation in solution. This hypothesis was supported by the fact that the ${ }^{11} \mathrm{~B}$ NMR shift of $\left[\mathrm{B}_{2} \mathrm{Cl}_{3}(\mathrm{IDip})_{2}\right]\left[\mathrm{BCl}_{4}\right]$ was highly concentration- and solvent-dependent, varying between 25 and $40 \mathrm{ppm}$ at room temperature. Due to the poor solubility of the species, however, and the fact that it could not be separated from $\mathrm{B}_{2} \mathrm{Cl}_{4}$ (IDip) $)_{2}$, no quantitative analysis of its fluxional solution behavior could be carried out. It is noteworthy that these ionic compounds were not observed as products of the 1:2 reactions of $\mathrm{B}_{2} \mathrm{Cl}_{4}$ with IMes or IDip, which suggests that it may only be accessible from the decomposition of the mono-adducts. While cationic monoboron(III) species, which are significantly more Lewis acidic than neutral boranes, are well-known and have found applications in catalysis, in particular, ${ }^{[30]}$ cationic diboron species like these remain relatively rare. Most known examples are dicationic bis(base)-stabilized $\mathrm{sp}^{2}-\mathrm{sp}^{2}$ - or $\mathrm{sp}^{3}-\mathrm{sp}^{3}$-diboron(II) compounds, ${ }^{[31],[32]}$ in which the electron-deficient boron centers are stabilized through $\pi$ donation by neutral and/or anionic nitrogen ligands, while Kinjo reported a unique tetrakis(carbene)stabilized $\mathrm{sp}^{3}$-sp ${ }^{3}$-diboron dication. ${ }^{[33]}$ Prior to the $\left[\mathrm{B}_{2} \mathrm{X}_{3} \mathrm{~L}_{2}\right] \mathrm{A}$ compounds presented herein, only a couple of examples of monocationic $\mathrm{sp}^{2}-\mathrm{sp}^{2}$-diboron(II) compounds had been reported, which were obtained by adding a single equivalent of IMes or IDip to $\mathrm{B}_{2} \mathrm{Br}_{2}\left(\mathrm{NMe}_{2}\right)_{2}$, resulting in the displacement of one bromide ligand. ${ }^{[34]}$

Attempts to obtain mixed-base adducts by adding a second Lewis base $\mathrm{L}$ to in-situ-formed $\mathrm{B}_{2} \mathrm{Cl}_{4}(\mathrm{NHC})$ at low temperature all resulted in statistical mixtures of $\mathrm{B}_{2} \mathrm{Cl}_{4}(\mathrm{NHC})_{2}, \mathrm{~B}_{2} \mathrm{Cl}_{4} \mathrm{~L}_{2}$ and $\mathrm{B}_{2} \mathrm{Cl}_{4}(\mathrm{NHC}) \mathrm{L}$ as determined by ${ }^{11} \mathrm{~B}$ NMR spectroscopic analysis. 


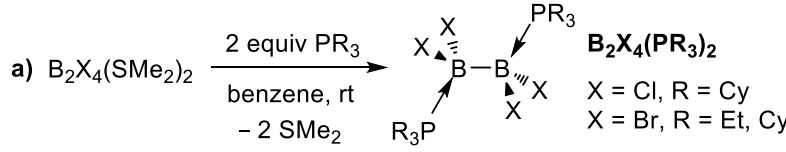

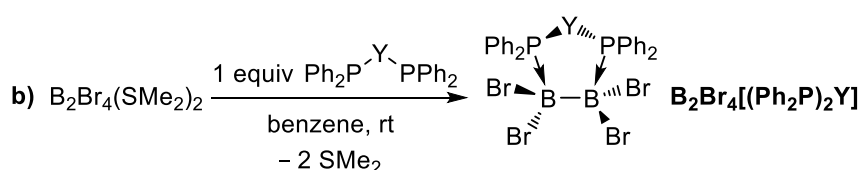

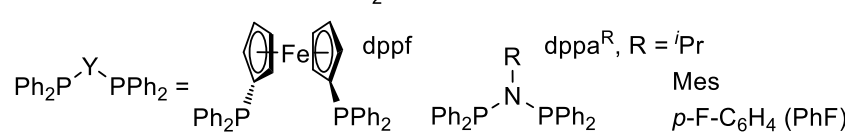

Scheme 6. Synthesis of new $B_{2} X_{4}$ bis(phosphine) and diphosphine-bridged adducts by ligand exchange at $\mathrm{B}_{2} \mathrm{X}_{4}\left(\mathrm{SMe}_{2}\right)_{2}(\mathrm{X}=\mathrm{Cl}, \mathrm{Br})$.
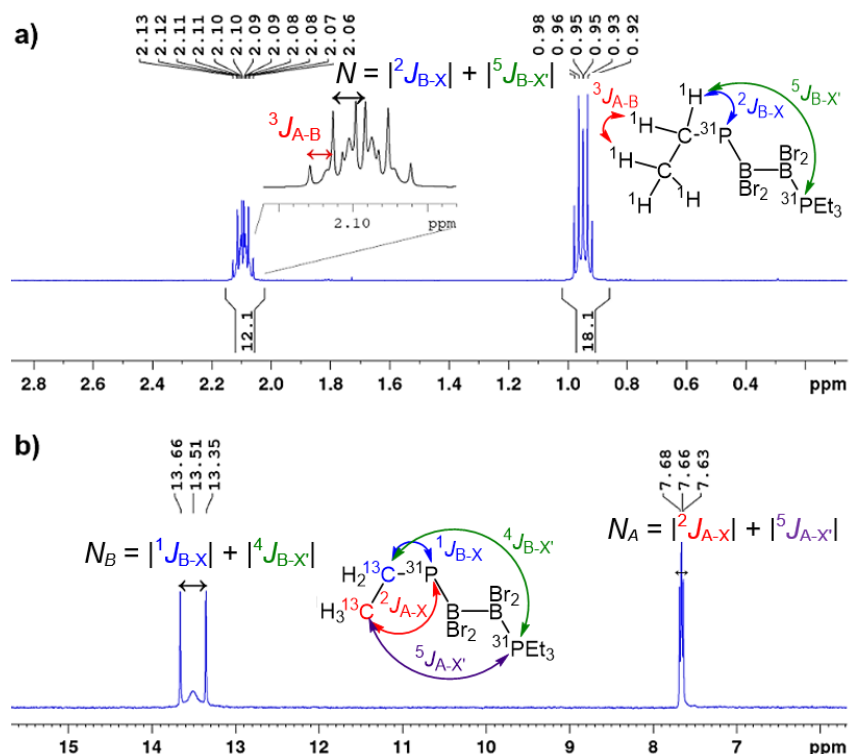

Figure 3. Higher-order spin coupling effects in the a) ${ }^{1} \mathrm{H}$ and b) ${ }^{13} \mathrm{C}\left\{{ }^{1} \mathrm{H}\right\}$ spectra of $\mathrm{B}_{2} \mathrm{Br}_{4}\left(\mathrm{PEt}_{3}\right)_{2}$.

To circumvent the numerous challenges associated with the synthesis, storage and handling of $\mathrm{B}_{2} \mathrm{Cl}_{4}$ and $\mathrm{B}_{2} \mathrm{Br}_{4},{ }^{[5],[7]}$ we sought to replace them with their dimethylsulfide bis-adducts, which are stable solids at room temperature under inert atmosphere and can be synthesized on a multigram scale from commercially available $\mathrm{B}_{2}\left(\mathrm{NMe}_{2}\right)_{4}$ and $\mathrm{BX}_{3}\left(\mathrm{SMe}_{2}\right)(\mathrm{X}=\mathrm{Cl}$ and $\mathrm{Br})$, respectively. ${ }^{[10]}$ It was hoped that the weakly binding $\mathrm{SMe}_{2}$ ligands could be easily displaced by stronger donor ligands to afford new $\mathrm{B}_{2} \mathrm{X}_{4}$ bis-adducts in higher yields. Indeed, ligand exchange reactions of $\mathrm{B}_{2} \mathrm{X}_{4}\left(\mathrm{SMe}_{2}\right)_{2}$ with two equivalents of a trialkylphosphine proceeded quantitatively to $\mathrm{B}_{2} \mathrm{X}_{4}\left(\mathrm{PR}_{3}\right)_{2}$ in benzene at room temperature over the course of $3 \mathrm{~h}$ (Scheme $6 a)$. Under the same conditions, $\mathrm{B}_{2} \mathrm{Br}_{4}\left(\mathrm{SMe}_{2}\right)_{2}$ underwent quantitative ligand exchange with various amino- and ferrocenylbridged bis(phosphines) at room temperature (Scheme 6b). The corresponding tetrachlorodiboron(6) analogues could also be obtained in a similar fashion but proved virtually insoluble in all suitable NMR and crystallization solvents, thus precluding further analysis.

Although chemically equivalent, the substituents of each of the two phosphine moieties in the $\mathrm{B}_{2} \mathrm{X}_{4}\left(\mathrm{PR}_{3}\right)_{2}$ and $\mathrm{B}_{2} \mathrm{X}_{4}\left(\mathrm{dppa}^{\mathrm{R}}\right)$ diboranes are magnetically inequivalent, with regards to their coupling to each of the ${ }^{31} \mathrm{P}$ nuclei. This leads to higher order effects for the ${ }^{1} \mathrm{H}$ and ${ }^{13} \mathrm{C}\left\{{ }^{1} \mathrm{H}\right\}$ resonances exhibiting ${ }^{31} \mathrm{P}$-coupling. In the case of $\mathrm{B}_{2} \mathrm{Br}_{4}\left(\mathrm{PEt}_{3}\right)_{2}$ shown in Fig. 3, for example, the ${ }^{1} \mathrm{H}$ NMR $\mathrm{PCH}_{2}$ resonance at $2.10 \mathrm{ppm}$ appears as a well-defined doublet of quartets overlapping with a broad virtual quartet. This unusual splitting pattern is owed to the existence of a complex ABXMM'X'B'A' spin system $\left(A / A^{\prime}=C_{3}, B / B^{\prime}=C H_{2}, X / X^{\prime}=\right.$ $\left.\mathrm{P} 1 / \mathrm{P} 2, \quad M / \mathrm{M}^{\prime}=\mathrm{B} 1 / \mathrm{B} 2\right)^{[35]}$ with strong coupling between the magnetically inequivalent pair of ${ }^{31} \mathrm{P}$ nuclei, as well as ${ }^{3} \mathrm{~J}\left(\mathrm{H}_{\mathrm{A}}-\mathrm{H}_{B}\right)$ and ${ }^{2} J\left(\mathrm{H}_{\mathrm{B}}-\mathrm{P} 1\right)$ couplings of similar magnitudes. The line broadening of the virtual signal is caused by the additional coupling to the fast-relaxing quadrupolar boron nuclei in the B-B bridge. In this spin system the virtual ${ }^{1} \mathrm{H}_{-}{ }^{31} \mathrm{P}$ coupling $N$, defined as the apparent peak separation of the two quartets, provides $\left.\right|^{2} J_{\text {HA-P1 }}|+|{ }^{5} J_{\text {HA-P2 }} \mid=10.9 \mathrm{~Hz}$. Conversely, the corresponding ${ }^{13} \mathrm{C}\left\{{ }^{1} \mathrm{H}\right\}$ NMR $\mathrm{PCH}_{2}$ resonance at $13.5 \mathrm{ppm}$ appears as a sharp doublet displaying a broad virtual resonance at its center, while the $\mathrm{CH}_{3}$ resonance at $7.7 \mathrm{ppm}$ appears as a virtual triplet. Here we have two AXMM'X'A' spin systems $\left(\mathrm{A} / \mathrm{A}^{\prime}=\mathrm{CH}_{2}\right.$ or $\mathrm{CH}_{3}, \mathrm{X} / \mathrm{X}^{\prime}=$ $\left.\mathrm{P} 1 / \mathrm{P} 2, \mathrm{M} / \mathrm{M}^{\prime}=\mathrm{B} 1 / \mathrm{B} 2\right)$, in which the virtual ${ }^{13} \mathrm{C}-{ }^{31} \mathrm{P}$ coupling $N$, defined as the separation between the two outer peaks, provides $\left|{ }^{1} J_{C H 2-\mathrm{P} 1}\right|+\left|{ }^{4} J_{C H 2-\mathrm{P} 2}\right|=38.6 \mathrm{~Hz}$ and $\left.\right|^{2} J_{C H 3-\mathrm{P} 1}|+|{ }^{5} J_{\mathrm{CH} 3-\mathrm{P} 2} \mid=5.4 \mathrm{~Hz}$. Similar higher order effects can be observed in the ${ }^{1} \mathrm{H}$ and ${ }^{13} \mathrm{C}\left\{{ }^{1} \mathrm{H}\right\}$ NMR spectra of all the $\mathrm{B}_{2} \mathrm{X}_{4}\left(\mathrm{PR}_{3}\right)_{2}$ and $\mathrm{B}_{2} \mathrm{X}_{4}\left(\mathrm{dppa}^{\mathrm{R}}\right)$ diboranes.

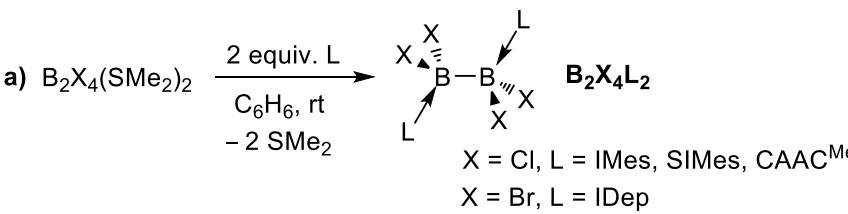

$$
\begin{aligned}
& \text { b) } \begin{aligned}
\mathrm{B}_{2} \mathrm{Cl}_{4}\left(\mathrm{SMe}_{2}\right)_{2} & \stackrel{2 \text { equiv. IDip }}{\stackrel{\mathrm{C}_{6} \mathrm{H}_{6}, 80{ }^{\circ} \mathrm{C}}{\longrightarrow}}\left[\begin{array}{c}
\left.\mathrm{B}_{\mathbf{2}} \mathrm{Cl}_{3}(\text { IDip })_{2}\right] \mathrm{BCl}_{\mathbf{4}}+\mathbf{B}_{\mathbf{2}} \mathrm{Cl}_{\mathbf{4}}(\text { IDip })_{2} \\
-2 \mathrm{SMe}_{2}
\end{array} \quad 3: 1(60 \% \text { conversion after } 24 \mathrm{~h})\right.
\end{aligned}
\end{aligned}
$$

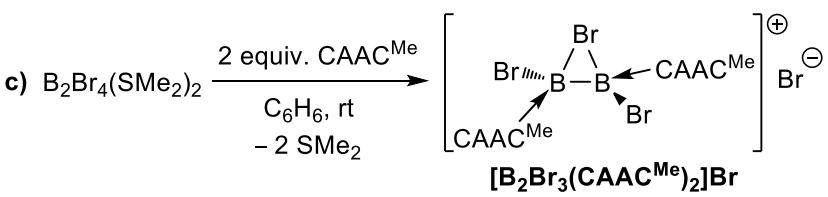

$$
\begin{aligned}
& \text { d) } 4 \text { NaNaph } \downarrow \text { THF, }-78^{\circ} \mathrm{C} \\
& \mathrm{CAAC}^{\mathrm{Me}}=\mathrm{B}=\mathrm{B}=\mathrm{CAAC}^{\mathrm{Me}}
\end{aligned}
$$

Scheme 7. Synthesis of bis(carbene) adducts by ligand exchange at $\mathrm{B}_{2} \mathrm{X}_{4}\left(\mathrm{SMe}_{2}\right)_{2}(\mathrm{X}=\mathrm{Cl}, \mathrm{Br})$.

Ligand exchange of $\mathrm{B}_{2} \mathrm{Cl}_{4}\left(\mathrm{SMe}_{2}\right)_{2}$ with SIMes and $\mathrm{CAAC}^{\mathrm{Me}}$, as well as $\mathrm{B}_{2} \mathrm{Br}_{4}\left(\mathrm{SMe}_{2}\right)_{2}$ with IDep proceeded rapidly and quantitatively at room temperature, yielding the corresponding $\mathrm{B}_{2} \mathrm{X}_{4} \mathrm{~L}_{2}$ bis-adducts (Scheme 7a). ${ }^{[36]}$ In contrast, the reaction of $\mathrm{B}_{2} \mathrm{Cl}_{4}\left(\mathrm{SMe}_{2}\right)_{2}$ with the highly sterically demanding IDip ligand did not proceed at room temperature but required prolonged heating, after which the ${ }^{11} \mathrm{~B}$ NMR spectrum showed only $60 \%$ conversion to a mixture of $\left[\mathrm{B}_{2} \mathrm{Cl}_{3}(\text { IDip) })_{2}\right] \mathrm{Cl}$ and $\mathrm{B}_{2} \mathrm{Cl}_{4}(\text { IDip) })_{2}$ (Scheme $7 \mathrm{~b}$ ). With $\mathrm{B}_{2} \mathrm{Br}_{4}\left(\mathrm{SMe}_{2}\right)_{2}$, less than $5 \%$ ligand exchange with IDip was observed after $24 \mathrm{~h}$ at $80^{\circ} \mathrm{C}$, the new broad NMR resonance at $38.5 \mathrm{ppm}$ suggesting the formation of ionic $\left[\mathrm{B}_{2} \mathrm{Br}_{3}(\mathrm{IDip})_{2}\right] \mathrm{Br}$, no resonance being observed around $-5 \mathrm{ppm}$ for the diborane(6) analogue, $\mathrm{B}_{2} \mathrm{Br}_{4}$ (IDip) ${ }_{2}{ }^{[20]}$ 
Interestingly, the outcome of the ligand exchange reaction of $\mathrm{B}_{2} \mathrm{Br}_{4}\left(\mathrm{SMe}_{2}\right)_{2}$ with $\mathrm{CAAC}{ }^{\mathrm{Me}}$ exclusively yielded bromide-bridged $\left[\mathrm{B}_{2} \mathrm{Br}_{3}\left(\mathrm{CAAC}^{\mathrm{Me}}\right)_{2}\right] \mathrm{Br}\left(\delta_{11 \mathrm{~B}}=7.8 \mathrm{ppm}\right.$, Scheme $\left.7 \mathrm{c}\right)$, whereas the direct addition of $\mathrm{CAAC}^{\mathrm{Me}}$ to $\mathrm{B}_{2} \mathrm{Br}_{4}$ affords the classical

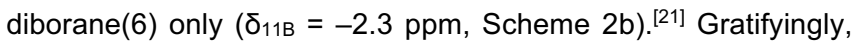
the reduction of $\left[\mathrm{B}_{2} \mathrm{Br}_{3}\left(\mathrm{CAAC} \mathrm{Ce}_{2}\right)_{2}\right] \mathrm{Br}$ with four equivalents of sodium naphthalenide in THF yields the diboracumulene $\mathrm{B}_{2}\left(\mathrm{CAAC}^{\mathrm{Me}}\right)_{2}$ (Scheme $7 \mathrm{~d}$ ) in similar yields to the reduction of $\mathrm{B}_{2} \mathrm{Br}_{4}\left(\mathrm{CAAC}^{\mathrm{Me}}\right)_{2}$ (Scheme 2b). ${ }^{[21]}$

The synthesis of $B_{2} X_{4} L_{2}$ (or $\left.\left[B_{2} X_{3} L_{2}\right] A\right)$ from $B_{2} X_{4}\left(S_{2}\right)_{2}(X$ $=\mathrm{Cl}, \mathrm{Br}$ ), room-temperature-stable solids, obtained in a single step and excellent yield from two commercial reagents,

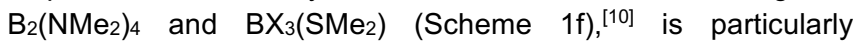
attractive as all these compounds are potential precursors for low-valent diboron species. Until now, the synthesis of such compounds relied on multi-step, low-yielding syntheses of pyrophoric and thermally unstable $\mathrm{B}_{2} \mathrm{X}_{4}$, also starting from commercial $\mathrm{B}_{2}\left(\mathrm{NMe}_{2}\right)_{4} \cdot{ }^{[9]}$ This new synthetic route also facilitates the scaling-up of syntheses, thus opening up new horizons for reactivity studies on these compounds.

\section{X-ray crystallographic analyses}

Colorless single crystals suitable for X-ray crystallographic analysis were obtained for the majority of the new tetrahalodiborane Lewis base adducts described above. The resulting solid-state structures are displayed in Figs. 1, 2, 4, 5 and 7 (see Figs. S68 - S70 in the SI for the solid-state structures of $\mathrm{B}_{2} \mathrm{Br}_{4}\left(\mathrm{PMe}_{2} \mathrm{Ph}\right)_{2}, \quad\left[\mathrm{~B}_{2} \mathrm{Cl}_{3}(\mathrm{IDip})_{2}\right]\left[\mathrm{BCl}_{4}\right] \quad$ and $\left.\left[\mathrm{B}_{2} \mathrm{Br}_{3}\left(\mathrm{CAAC}{ }^{\mathrm{Me}}\right)_{2}\right] \mathrm{Br}\right)^{[37]}$ while relevant bond lengths and angles are provided in Table 1.

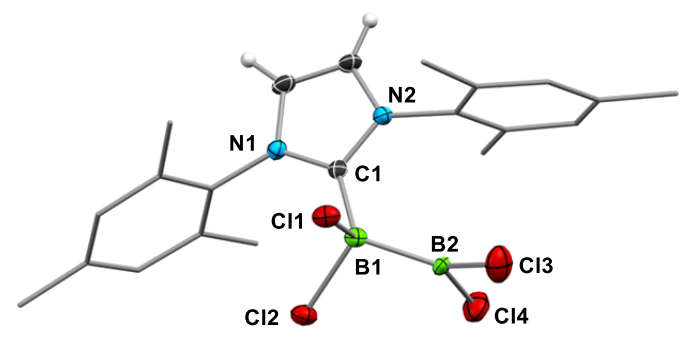

Figure 4. Crystallographically-derived molecular structure of $\mathrm{B}_{2} \mathrm{Cl}_{4}$ (IMes). Thermal ellipsoids drawn at $50 \%$ probability level. Ellipsoids on the ligand peripheries and most hydrogen atoms omitted for clarity.

A tetrahalodiborane(5). X-ray crystallographic analysis of the mono-adduct $\mathrm{B}_{2} \mathrm{Cl}_{4}$ (IMes) (Fig. 4) confirmed the unsymmetrical nature of the compound, which displays one planar $\mathrm{sp}^{2}$-borane moiety at $\mathrm{B} 2\left(\Sigma(\angle \mathrm{B} 2) 359.8(2)^{\circ}\right)$ and one tetrahedral $\mathrm{sp}^{3}$-borane moiety at B1 (B2-B1-Cl3 103.45(19); B2-B1-Cl2 111.8(2); B2-

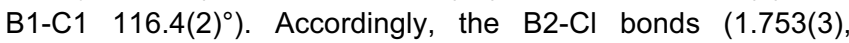
$1.764(4) \AA)$ are significantly shorter than the $\mathrm{B} 1-\mathrm{Cl}$ bonds (1.882(3), 1.893(3) $\AA$ ), similarly to the variation in $\mathrm{B}-\mathrm{Br}$ bond lengths in Kinjo's tetrabromodiborane(5), $\mathrm{B}_{2} \mathrm{Br}_{4}(\mathrm{CAAC}) \cdot{ }^{\mathrm{B} 3]}$ Comparison with the corresponding bis(IMes) adduct, $\mathrm{B}_{2} \mathrm{Cl}_{4}(\mathrm{IMes})_{2}$ (Fig. 1), shows much shorter B-B and B-C bonds in $\mathrm{B}_{2} \mathrm{Cl}_{4}$ (IMes) $(1.719(4)$ and $1.619(4) \AA$, respectively) versus $\mathrm{B}_{2} \mathrm{Cl}_{4}(\mathrm{IMes})_{2}(1.760(4)$ and $1.645(3), 1.646(3) \AA$, respectively) as expected for the lower coordination number. In recent years $\mathrm{sp}^{2}-$ $\mathrm{sp}^{3}$-diboranes have gained in popularity due to their potential as sources of a nucleophilic boryl moiety ${ }^{[2]}$ and numerous examples have now been structurally characterized. ${ }^{[38]}$ However, besides
$\mathrm{B}_{2} \mathrm{Br}_{4}\left(\mathrm{CAAC}^{\mathrm{B}}\right),{ }^{[23]} \mathrm{B}_{2} \mathrm{Cl}_{4}$ (IMes) is only the second example of a crystallographically characterized tetrahalodiborane(5).

Diborane(6) adducts of monodentate ligands. For a given halogen $X$ the $B-B$ bond length of the $B_{2} X_{4} L_{2}$ diborane(6) compounds seems more dependent on the steric than the electronic properties of $\mathrm{L}$. Thus the $\mathrm{B}-\mathrm{B}$ bond in $\mathrm{B}_{2} \mathrm{Br}_{4}(\mathrm{CNDip})_{2}$ $(1.732(3) \AA)$ is significantly longer than in $B_{2} \mathrm{Br}_{4}(\mathrm{CN} t \mathrm{Bu})_{2}$ $(1.716(5) \AA)$ despite $\mathrm{CNtBu}$ being the stronger donor, while $\mathrm{B}_{2} \mathrm{Cl}_{4}\left(\mathrm{SMe}_{2}\right)_{2}$ and $\mathrm{B}_{2} \mathrm{Cl}_{4}\left(\mathrm{PMe}_{3}\right)_{2}$ display identical $\mathrm{B}-\mathrm{B}$ bond lengths $\left(1.719(2)\right.$ and $1.718(3) \AA$, respectively), despite $\mathrm{PMe}_{3}$ being a significantly stronger donor than $\mathrm{SMe}_{2}$. As expected, the $B-B$ bonds in these $B_{2} X_{4} L_{2}$ compounds are significantly shorter than in the few structurally characterized $B_{2} \mathrm{H}_{4} \mathrm{~L}_{2}$ tetrahydrodiborane(6) counterparts $(\mathrm{L}=\mathrm{IMes}$ : $1.795(5) \AA ;[39]$ IDip: $1.828(4) \AA ;\left[{ }^{[17]} \mathrm{PPh}_{3}: 1.76(2) \AA\right),{ }^{[40]}$ due to the more electronegative halides drawing electron density out of the B-B bond.
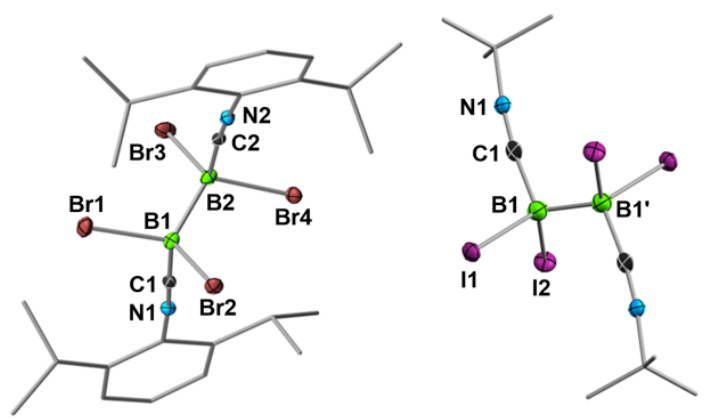

Figure 5. Crystallographically-derived molecular structures of the bis-isonitrile adducts (from left to right) $\mathrm{B}_{2} \mathrm{Br}_{4}(\mathrm{CNDip})_{2}$ and $\mathrm{B}_{2} \mathrm{l}_{4}(\mathrm{CN} t \mathrm{Bu})_{2}$. Thermal ellipsoids drawn at $50 \%$ probability level. Ellipsoids on the ligand peripheries and hydrogen atoms omitted for clarity.

Interestingly, there is little B-B bond length variation for a given ligand $L$ when varying the halogen $X$. This is best exemplified by the virtually identical $B-B$ bond lengths in $\mathrm{B}_{2} \mathrm{X}_{4}\left(\mathrm{SMe}_{2}\right)_{2}$ of 1.719(2), 1.715(4) $\AA$ and 1.714(7) for $X=\mathrm{Cl}, \mathrm{Br}$ and $\mathrm{I}$, respectively. The same observation can be made for bis(phosphine) adducts such as $\mathrm{B}_{2} \mathrm{X}_{4}\left(\mathrm{PMe}_{3}\right)_{2}$ ( $\mathrm{B}-\mathrm{B}$ 1.718(3), 1.713(3) and 1.727(7) $\AA$ for $X=\mathrm{Cl}, \mathrm{Br}$ and I, respectively), bis(NHC) adducts such as $\mathrm{B}_{2} \mathrm{X}_{4}(\mathrm{IDipiPr})_{2}$ (B-B 1.757(4) and $1.764(4) \AA$ for $\mathrm{X}=\mathrm{Cl}$ and $\mathrm{Br}$, respectively) and the bis $\left(\mathrm{CAAC}^{\mathrm{Me}}\right.$ ) adducts (B-B 1.758(5) - 1.763(3) and 1.754(5) $\AA$ for $\mathrm{X}=\mathrm{Cl}$ and $\mathrm{Br}$, respectively). The only significant outlier is the tetraiododiborane(6) bis(isonitrile) adduct $\mathrm{B}_{2} \mathrm{l}_{4}(\mathrm{CNtBu})_{2}$ (Fig. 4), which displays a very short $B-B$ bond length of $1.675(16) \AA$, ca. $0.04 \AA$ shorter than that of its bromide analogue (1.716(5) $\AA$ ). Among classical diborane(6) compounds there are few examples of shorter B-B single bonds, including a bipyridinebridged bis(benzene1,2-dithiolate) diborane (B-B 1.65(5) $\AA$ ), ${ }^{[35]}$ in which the shortening of the B-B bond is enforced by the bridging ligand.

All the $B_{2} X_{4} L_{2}$ diboranes(6) in which $L$ is a monodentate donor ligand display a staggered anti-conformation of the ligands. For the smallest ligands (e.g. $\mathrm{SMe}_{2}, \mathrm{PMe}_{2}, \mathrm{NMe}_{3}$, $\mathrm{CN} t \mathrm{Bu}$ ), the structure tends to be centrosymmetric, with an $(L, B, B, L)$ torsion angle $\alpha$ of $180^{\circ}$ (Fig. 6), which then widens with the steric demands of the ligands. This is best exemplified by the extensive series of $\mathrm{B}_{2} \mathrm{Br}_{4} \mathrm{~L}_{2}$ analogues, in which the torsion angle $\alpha$ follows the increase in steric demands of $\mathrm{L}: \mathrm{SMe}_{2} \approx \mathrm{PMe}_{3}$ 
$\left(180^{\circ}\right) \approx \mathrm{CNtBu}\left(177.7(3)^{\circ}\right)<\mathrm{CNDip}\left(172.9(2)^{\circ}\right)<\mathrm{PiPr}_{3}$ $\left(167.1(1)^{\circ}\right)<\mathrm{PCy}_{3}\left(163.1(2)^{\circ}\right)<\operatorname{IDep}\left(159.2(3)^{\circ}\right)<\mathrm{IDipiPr}$ $\left(151.4(2)^{\circ}\right)$. The only outlier in this series is $\mathrm{B}_{2} \mathrm{Br}_{4}\left(\mathrm{CAAC}^{\mathrm{Me}}\right)_{2}$, which displays a $(C, B, B, C)$ torsion angle of $177.3(3)^{\circ}$ despite the high steric demands of the $C A A C^{M e}$ ligand. Similarly, the $(C, B, B, C)$ torsion angle of $\mathrm{B}_{2} \mathrm{Cl}_{4}\left(\mathrm{CAAC}^{\mathrm{Me}}\right)_{2}$ is close to $180^{\circ}$, which suggests that electronic factors override sterics for this particular ligand. Moreover, with the exception of $\mathrm{B}_{2} \mathrm{Cl}_{4}(\mathrm{liPr})_{2}$, in which the two NHC rings are coplanar, the mean planes of the $\mathrm{NHC}$ or CAAC rings in the other bis-carbene adducts form an angle $\beta$ (Fig. $X$ ) ranging from ca. $57^{\circ}$ in $\mathrm{B}_{2} \mathrm{Br}_{4}(\text { IDipiPr) })_{2}$ to ca. $79^{\circ}$ in $\mathrm{B}_{2} \mathrm{Cl}_{4}\left(\mathrm{CAAC}^{\mathrm{Me}}\right)_{2}$, albeit without any obvious steric-dependent trend, suggesting an interplay between sterics and packing forces. Furthermore, again with the exception of $\mathrm{B}_{2} \mathrm{Cl}_{4}(\mathrm{liPr})_{2}$ and $\mathrm{B}_{2} \mathrm{Cl}_{4}\left(\mathrm{CAAC}{ }^{\mathrm{Me}}\right)_{2}$, one of the $\mathrm{B}-\mathrm{X}$ bonds at each boron center tends to align with the $\pi$ framework of the adjacent carbene ligand, as seen by the relatively small $(\mathrm{X}, \mathrm{B}, \mathrm{C}, \mathrm{N})$ torsion angles $\mathrm{Y}$, ranging from 0 and $4^{\circ}$ in $\mathrm{B}_{2} \mathrm{Cl}_{4}(\mathrm{IDipiPr})_{2}$ to 9 and $14^{\circ}$ in $\mathrm{B}_{2} \mathrm{Cl}_{4}(\mathrm{IMes})_{2}$, presumably to maximize orbital overlap with the $\pi$ electrons of the halide ligand.
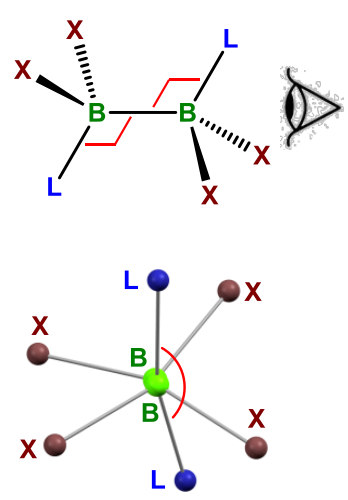

$=(\mathrm{L}, \mathrm{B}, \mathrm{B}, \mathrm{L})$ torsion angle

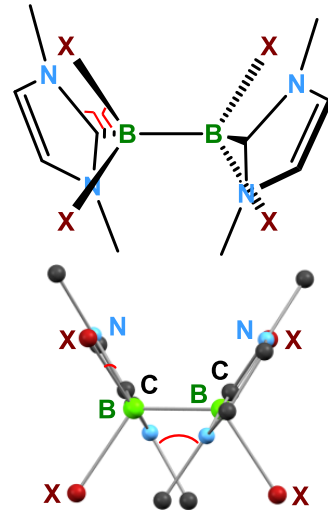

$=$ angle between carbene ring planes $=(\mathrm{X}, \mathrm{B}, \mathrm{C}, \mathrm{N})$ torsion angle

Figure 6. Schematic representation of the $(L, B, B, L)$ torsion angle $\alpha$ in $B_{2} X_{4} L_{2}$ compounds, as well as the angle $\beta$ between the mean planes of the carbene rings and the $(X, B, C, N)$ torsion angle $\mathrm{Y}$ in $\mathrm{B}_{2} \mathrm{X}_{4}$ (carbene) $)_{2}$ compounds.

It is noteworthy that, with the exception of the recently published $\mathrm{B}_{2} \mathrm{Br}_{4}\left(\mathrm{PCy}_{3}\right)_{2},{ }^{[26]}$ the tetrabromodiborane bis(phosphine) adducts presented herein are among the first crystallographically characterized compounds of their kind. Furthermore, $\mathrm{B}_{2} \mathrm{I}_{4}(\mathrm{CNtBu})_{2}$ is the first structurally characterized tetraiododiborane bis(isonitrile) adduct.

Diborane(6) adducts of bridging diphosphine ligands. Here again, the $\mathrm{B}-\mathrm{B}$ distance is governed by the sterics of the diphosphine spacer: while $\mathrm{B}_{2} \mathrm{Br}_{4}\left(\mathrm{dppa}^{i \mathrm{Pr}}\right) \quad\left(\mathrm{dppa}^{\mathrm{iPr}}=\right.$ bis(diphenylphosphine)isopropylamine) and $\mathrm{B}_{2} \mathrm{Br}_{4}\left(\mathrm{dppa}^{\mathrm{PhF}}\right)$ $\left(\mathrm{dppa}^{\mathrm{PhF}}=\right.$ bis(diphenylphosphine)-p-fluoroaniline), with their small amino spacer, display identical B-B bond lengths (1.714(7) and $1.713(3) \AA$, respectively), similar to those of the less sterically demanding $\mathrm{B}_{2} \mathrm{Br}_{4}\left(\mathrm{PR}_{3}\right)_{2}$ adducts $\left(\mathrm{R}_{3}=\mathrm{Me}_{3}, \mathrm{Et}_{3}, \mathrm{Me}_{2} \mathrm{Ph}\right.$ : $\mathrm{B}-\mathrm{B} 1.708(7)-1.718(5) \quad \AA$ ),$\quad \mathrm{B}_{2} \mathrm{Br}_{4}(\mathrm{dppf}) \quad\left(\mathrm{dppf}=1,1^{\prime}-\right.$ bis(diphenylphosphine)ferrocene), with its large ferrocene spacer, displays a much longer B-B bond of 1.752(6) A. Furthermore, the $(P, B, B, P)$ torsion angle widens with the size of the spacer, from $\mathrm{NPhF}\left(22.6(1)^{\circ}\right)$ over $\operatorname{NiPr}\left(32.7(3)^{\circ}\right)$ to $\mathrm{Fc}$

$\left(50.5(5)^{\circ}\right)$, as the molecule strives to reach a staggered gauche conformation with minimal ligand repulsion. The effect of the ligand electronics is seen in the two dppa analogues: the $\mathrm{B}-\mathrm{Br}$ bonds of the more electron-withdrawing $\mathrm{dppa}^{\mathrm{PhF}}$ derivative (2.058(2), 2.068(2) $\AA$ ) are slightly longer than in the dppa $\mathrm{a}^{\mathrm{PP}}$ derivative $(2.027(5)-2.042(5) \AA$ ) while the B-P bonds in the former $(1.956(2) \AA)$ are significantly shorter than in the latter (1.980(5), 1.995(5) Å). While bridging diphosphines have been employed to stabilize cyclic cis-1,2-diaryl-diborenes, ${ }^{[42]}$ the diphosphine-bridged diboranes presented herein are the first to have been structurally characterized.

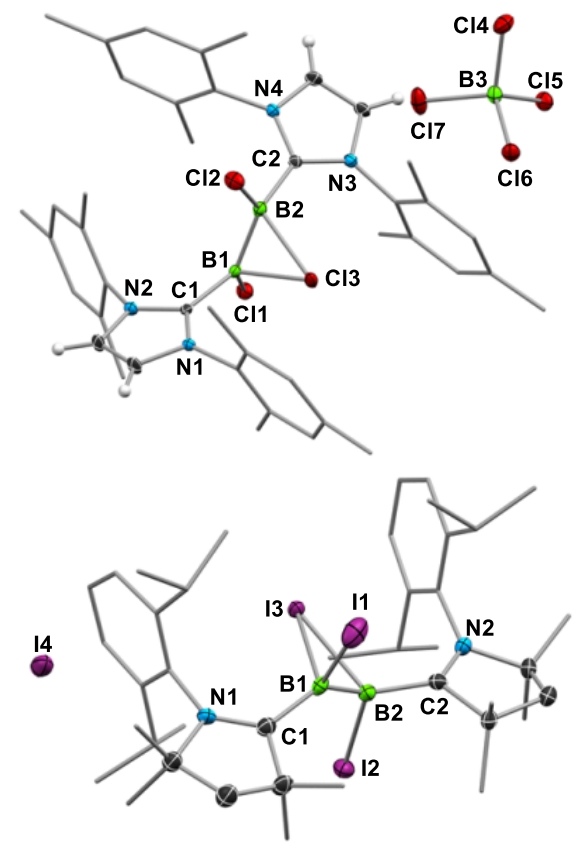

Figure 7. Crystallographically-derived molecular structures of the halidebridged ionic bis-carbene adducts $\left[\mathrm{B}_{2} \mathrm{Cl}_{3}(\mathrm{IMes})_{2}\right] \mathrm{BCl}_{4}$ (top) and $\left[\mathrm{B}_{2} \mathrm{I}_{3}\left(\mathrm{CAAC}{ }^{\mathrm{Me}}\right)_{2}\right]$ l (bottom). Thermal ellipsoids drawn at $50 \%$ probability level. Ellipsoids on the ligand peripheries and most hydrogen atoms omitted for clarity.

Ionic $\left[B_{2} X_{3} L_{2}\right] A$ compounds. While hydrodiboranes are wellknown to form $\mu^{2}$-hydride-bridged structures displaying threecenter-two-electron bonding, examples of $\mu^{2}$-halogen-bridged diboranes are much rarer. To date only a handful of such structures, albeit of neutral, mono(base)-stabilized dihalodiboranes, have been reported: a series of $\mu^{2}$-halidebridged phosphine adducts of $\mathrm{B}_{2} \mathrm{X}_{2} \mathrm{Mes}_{2}(\mathrm{X}=\mathrm{Cl}, \mathrm{Br}, \mathrm{I}$; Mes = 2,4,6- $\left.-\mathrm{Me}_{3} \mathrm{C}_{6} \mathrm{H}_{2}\right),{ }^{[43]}$ a series of $\mu^{2}$-chloro-bridged pyridine adducts of $\mathrm{B}_{2} \mathrm{Cl}_{2} \mathrm{Ar}_{2}\left(\mathrm{Ar}=\mathrm{Mes}\right.$, Dur $\left.=2,3,5,6-\mathrm{Me}_{4} \mathrm{C}_{6} \mathrm{H}\right)$ and a $\mu^{2}$-iodobridged $1,2,3$-azadiborolidine. ${ }^{[44]}$ Similarly to these two species, the two boron, terminal halogen and carbene carbon atoms in $\left[\mathrm{B}_{2} \mathrm{Cl}_{3}(\mathrm{IMes})_{2}\right] \mathrm{BCl}_{4}$ and $\left[\mathrm{B}_{2} \mathrm{I}_{3}\left(\mathrm{CAAC}{ }^{\mathrm{Me}}\right)_{2}\right] \mathrm{l}$ (Fig. 7) are quasicoplanar, with a maximum deviation from the mean $\mathrm{B}_{2}\left(\mathrm{X}_{\mathrm{t}}\right)_{2} \mathrm{C}_{2}$ plane $\left(X_{t}=\right.$ terminal halide $)$ of 0.15 and $0.24 \AA$, respectively. In both cases, the $\mathrm{B}_{2}\left(\mathrm{X}_{\mathrm{t}}\right)_{2} \mathrm{C}_{2}$ plane lies perpendicular to that of the $\mathrm{B}_{2} \mathrm{X}_{\mathrm{b}}$ heterocycle $\left(\mathrm{X}_{\mathrm{b}}=\text { bridging halide }\right)^{[44]}$ and presents a trans arrangement of the halide and carbene ligands, the latter being rotated such that the bridging halide is flanked on either side by one aryl group. A comparison of $\mathrm{B}_{2} \mathrm{Cl}_{4}(\mathrm{IMes})_{2}$ and its chloridebridged analogue $\left[\mathrm{B}_{2} \mathrm{Cl}_{3}(\mathrm{IMes})_{2}\right] \mathrm{BCl}_{4}$ shows considerable shortening of the B-B bond from $1.760(4)$ to $1.667(3) \AA$, 
concomitant with a ca. $4 \%$ shortening of the $\mathrm{B}-\mathrm{Cl}_{\mathrm{t}}$ and $\mathrm{B}-\mathrm{C}_{\mathrm{IMes}}$ bonds, due to the bridging halide effectively lowering the coordination number of the boron atoms to less than four. Despite the much larger size of the iodide ligand compared to the chloride, the $\mathrm{B}-\mathrm{B}$ bond length in $\left[\mathrm{B}_{2} \mathrm{I}_{3}\left(\mathrm{CAAC}^{\mathrm{Me}}\right)_{2}\right] \mathrm{l}(1.678(8)$ $A)$ is not significantly longer than in $\left[\mathrm{B}_{2} \mathrm{Cl}_{3}(\mathrm{IMes})_{2}\right] \mathrm{BCl}_{4}(1.667(3)$ $A)$. The $B-X_{b}$ bonds are elongated by ca. $13 \%$ in $\left[\mathrm{B}_{2} \mathrm{Cl}_{3}(\mathrm{IMes})_{2}\right] \mathrm{BCl}_{4}$ and $7 \%$ in $\left[\mathrm{B}_{2} \mathrm{I}_{3}\left(\mathrm{CAAC}^{\mathrm{Me}}\right)_{2}\right] \mathrm{l}$ compared to the $\mathrm{B}-\mathrm{X}_{\mathrm{t}}$ bonds (Table 1 ). Unlike the two previously reported unsymmetrically halide-bridged diborane mono-adducts, ${ }^{[35][44]}$ the presence of the two Lewis bases in the ionic $\left[B_{2} X_{3} L_{2}\right] A$ species generates a pseudo- $C_{2 v}$ symmetry around the axis passing through the bridging halide and the center of the $B-B$ bond, leading to two relatively similar $B-X_{b}$ bond lengths $\left(B-C_{b}\right.$ 2.033(2), 2.078(3) $\AA$; B-lb 2.400(5), 2.422(5) $\AA$ ) and B-B- $X_{b}$ angles (B-B-Clb 64.66(12), 67.51(12) ${ }^{\circ}$; B-B-lb 69.0(3), 70.3(3) ${ }^{\circ}$ ) in each case, suggesting that the two electrons are equally shared between the two $\mathrm{B}-\mathrm{X}_{\mathrm{b}}$ bonds.

\section{Conclusions}

To conclude, we have synthesized, isolated and characterized a series of new bis(base)-stabilized tetrahalodiboranes through the addition of two equivalents of phosphines, isonitriles, NHCs and CAACs to $\mathrm{B}_{2} \mathrm{X}_{4}$ precursors $(\mathrm{X}=\mathrm{Cl}, \mathrm{Br}, \mathrm{I})$. For the majority of these ligands classical $B_{2} X_{4} L_{2}$ diborane(6) adducts were obtained, but for some of the most sterically demanding carbene ligands $\left(\mathrm{L}=\mathrm{IMes}, \mathrm{IDip}, \mathrm{CAAC}^{\mathrm{Me}}\right)$, ionic halide-bridged compounds of the form $\left[\mathrm{B}_{2} \mathrm{X}_{3} \mathrm{~L}_{2}\right] \mathrm{A}\left(\mathrm{X}=\mathrm{Cl}, \mathrm{A}=\mathrm{BCl}_{4} ; \mathrm{X}=\mathrm{A}=\mathrm{Br}\right.$, I) were isolated, which in reduction reactions yield the same products as their $\mathrm{B}_{2} \mathrm{X}_{4} \mathrm{~L}_{2}$ diborane $(6)$ counterparts. At $-70{ }^{\circ} \mathrm{C}$ the $1: 1$ addition of IMes and IDip to $\mathrm{B}_{2} \mathrm{Cl}_{4}$ afforded the unsymmetrical diborane(5) mono-adducts, $\mathrm{B}_{2} \mathrm{Cl}_{4} \mathrm{~L}$, one of which was crystallographically characterized. Upon warming these highly unstable compounds disproportionated to the corresponding ionic $\left[\mathrm{B}_{2} \mathrm{X}_{3} \mathrm{~L}_{2}\right] \mathrm{A}$ species. Furthermore, we showed that $\mathrm{L} / \mathrm{SMe}_{2}$ ligand exchange at stable $\mathrm{B}_{2} \mathrm{X}_{4}\left(\mathrm{SMe}_{2}\right)_{2}$ precursors $(\mathrm{X}=\mathrm{Cl}, \mathrm{Br})$ provides a more facile and scalable route towards bis(base)-stabilized tetrahalodiboranes.

The ${ }^{11} \mathrm{~B}$ NMR shifts of the new and literature-known $\mathrm{B}_{2} \mathrm{X}_{4} \mathrm{~L}_{2}$ species show a strong dependency on the nature of both $X$ and L. While a relatively small upfield shift of 5 to $8 \mathrm{ppm}$ is observed upon moving from $\mathrm{Cl}$ to $\mathrm{Br}$ for a given ligand $\mathrm{L}$, a much higher upfield shift of 20 to $25 \mathrm{ppm}$ is observed upon replacing $\mathrm{Br}$ with I, in line with the relative decrease in electronegativity down the halogen group. For a given halogen, the ${ }^{11} \mathrm{~B}$ NMR shift is dependent on the overall donor ability of $\mathrm{L}$, with a ca. $16 \mathrm{ppm}$ upfield shift between the weakest $\left(\mathrm{SMe}_{2}\right)$ and strongest donor employed (CNtBu). Furthermore, ${ }^{1} \mathrm{H}$ and ${ }^{13} \mathrm{C}$ NMR spectroscopic analysis of bis(phosphine)- and amino-bridged diphosphinestabilized tetrabromodiboranes revealed higher order effects caused by the existence of complex ABXMM'X'B'A' and AXMM'X'A' spin systems, involving the ${ }^{1} \mathrm{H}$ and ${ }^{13} \mathrm{C}$ nuclei, respectively, as well as the two magnetically inequivalent ${ }^{31} \mathrm{P}$ nuclei, which strongly couple to each other via the quadrupolar B-B bridge.

Of the 22 isolated tetrahalodiborane bis-adducts, 20 were crystallographically characterized. Structural analyses of new and literature-known $B_{2} X_{4} L_{2}$ compounds, in which $L$ is a monodentate ligand, show a strong preference for a staggered anti-conformation of the ligands with respect to the B-B axis.
While the nature of the halogens has seemingly little effect on the geometry of the molecules, the electronic and steric properties of $L$ greatly influences the $B-B$ bond length and the ligand conformation, respectively. In the ionic $\left[B_{2} X_{3} L_{2}\right] A$ species the $\mathrm{B}-\mathrm{X}-\mathrm{B}$ bridge displays symmetrical three-center-two-electron bonding and lies perpendicular to the near-planar $\mathrm{B}_{2} \mathrm{X}_{2} \mathrm{~L}_{2}$ core.

While tetrahalodiborane Lewis base adducts have long been neglected because of the lengthy, low-yielding syntheses and instability of their $\mathrm{B}_{2} \mathrm{X}_{4}$ precursors, the new synthetic route via ligand exchange with the readily scalable and easy-to-handle $\mathrm{B}_{2} \mathrm{X}_{4}\left(\mathrm{SMe}_{2}\right)_{2}$ precursors now opens up the possibility of studying these compounds on a larger scale. Having already proven their worth as precursors for mono- and zero-valent diboron species, their reactivity in anion exchange, salt metathesis, B-B-bond cleavage and addition reactions remains to be explored.

\section{Acknowledgements}

The authors thank the Deutsche Forschungsgemeinschaft and the European Research Council (ERC) under the European Union Horizon 2020 Research and Innovation Program (BoronBoron Multiple Bonding, Advanced Grant agreement no. 669054, to H.B.) for funding.

\section{Conflict of interest}

The authors declare no conflict of interest.

Keywords: Diborane(6) $\bullet$ Lewis base adduct $\cdot$ Ligand exchange - Crystallography $\cdot$ NMR spectroscopy

[1] a) F. Zhao, X. Jia, P. Li, J. Zhao, Y. Zhou, J. Wang, H. Liu, Org. Chem. Front. 2017, 4, 2235-2255; b) J. W. B. Fyfe, A. J. B. Watson, Chem 2017, 3, 31-55; c) E. C. Neeve, S. J. Geier, I. A. I. Mkhalid, S. A. Westcott, T. B. Marder, Chem. Rev. 2016, 116, 9091-9161; d) A. Ros, R. Fernández, J. M. Lassaletta, Chem. Soc. Rev. 2014, 43, 3229-3243; e) J. R. Coombs, F. Haeffner, L. T. Kliman, J. P. Morken, J. Am. Chem. Soc. 2013, 135, 11222-11231.

[2] a) Y. Wen, C. Deng, J. Xie, X. Kang, Molecules 2019, 24, 101; b) R. D. Dewhurst, E. C. Neeve, H. Braunschweig, T. B. Marder, Chem. Commun. 2015, 51, 9594-9607

[3] a) A. Verma, W. L. Santos, ACS Symp. Ser. 2016, 1236, 313-356; b) A. J. J. Lennox, G. C. Lloyd-Jones, Chem. Soc. Rev. 2014, 43, 412-443; C) A. Suzuki, Y. Yamamoto, Chem. Lett. 2011, 40, 894-901.

[4] A. Stock, A. Brandt, H. Fischer, Chem. Ber. 1925, 58, 643-657.

[5] T. Wartik, R. Moore, H. I. Schlesinger, J. Am. Chem. Soc. 1949, 71, 3265-3266.

[6] A. Finch, H. I. Schlesinger, J. Am. Chem. Soc. 1958, 80, 3573-3574.

[7] G. Urry, T.Wartik, R. E. Moore, H. I. Schlesinger, J. Am. Chem. Soc. 1954, 76, 5293-5298.

[8] W. Haubold, P. Jacob, Z. Anorg. Allg. Chem. 1983, 507, 231-234.

[9] H. Nöth, H. Pommerening, Chem. Ber. 1981, 114, 398-399.

[10] M. Arrowsmith, J. Böhnke, H. Braunschweig, A. Deißenberger, R. D. Dewhurst, W. C. Ewing, C. Hörl, J. Mies, J. H. Müssig, Chem. Commun. 2017, 53, 8265-8267.

[11] a) B. W. C. Ashcroft, A. K. Holliday, Inorg. Phys. Theor. J. Chem. Soc. (A) 1971, 2581-2583; b) W. Haubold, U. Kraatz, W. Einholz, Z. Anorg. Allg. Chem. 1991, 592, 35-41.

[12] T. Wartik, E. F. Apple, J. Am. Chem. Soc. 1958, 80, 6155-6158.

[13] A. G. Garrett, G. Urry, Inorg. Chem. 1963, 2, 400-405.

[14] W. Keller, L. G. Sneddon, W. Einholz, A. Gemmler, Chem. Ber. 1992 , 125, 2343-2346.

[15] A. K. Holliday, F. J. Marsden, A. G. Massey, J. Chem. Soc. 1961, 33483352. 
[16] R. Schaeffer, Q. Johnson, J. Kane, J. Am. Chem. Soc. 1970, 92, 76147615.

[17] F. J. Lawlor, N. C. Norman, N. L. Pickett, E. G. Robins, P. Nguyen, G. Lesley, T. B. Marder, J. A. Ashmore, J. C. Green, Inorg. Chem. 1998 37, 5282-5288

[18] Y. Wang, B. Quillian, P. Wei, C. S. Wannere, Y. Xie, R. B. King, H. F. Schaefer, P. v. R. Schleyer, G. H. Robinson, J. Am. Chem. Soc. 2007 129, 12412-12413.

[19] Holzmann, A. Stasch, C. Jones, G. Frenking, Chem. Eur. J. 2011, 17 13517-13525.

[20] H. Braunschweig, R. D. Dewhurst, K. Hammond, J. Mies, K. Radacki, A Vargas, Science 2012, 336, 1420-1422.

[21] J. Böhnke, H. Braunschweig, W. C. Ewing, C. Hörl, T. Kramer, I. Krummenacher, J. Mies, A. Vargas, Angew. Chem. Int. Ed. 2014, 53, 9082-9085.

[22] a) J. Böhnke, H. Braunschweig, T. Dellermann, W. C. Ewing, K. Hammond, J. O. C. Jimenez-Halla, T. Kramer, J. Mies, Angew. Chem. Int. Ed. 2015, 54, 13801-13805; b) M. Arrowsmith, J. Böhnke, H. Braunschweig, M. A. Celik, T. Dellermann, K. Hammond, Chem. Eur. J. 2016, 22, 17169-17172.

[23] W. Lu, Y. Li, R. Ganguly, R. Kinjo, J. Am. Chem. Soc. 2017, 139 5047-5050.

[24] W. Lu, Y. Li, R. Ganguly, R. Kinjo, Angew. Chem. Int. Ed. 2017, 56, 9829-9832.

[25] a) Y. Katsuma, N. Tsukahara, L. Wu, Z. Lin, M. Yamashita, Angew Chem. Int. Ed. 2018, 57, 6109-6114; b) N. Arnold, H. Braunschweig, W. C. Ewing, T. Kupfer, K. Radacki, T. Thiess, A. Trumpp, Chem. Eur. J 2016, 22, 11441-11449; c) J. Böhnke, H. Braunschweig, T. Dellermann, W. C. Ewing, T. Kramer, I. Krummenacher, A. Vargas, Angew. Chem. Int. Ed. 2015, 54, 4469-4473; d) H. Asakawa, K.-H. Lee, Z. Lin, M. Yamashita, Nature Commun. 2014, 5, 4245; e) S. Pospiech, M. Bolte H.-W. Lerner, M. Wagner, Organometallics 2014, 33, 6967-6974; f) J. Teichmann, H. Stock, H. Pritzkow, W. Siebert, Eur. J. Inorg. Chem. 1998, 4, 459-463; g) S. Luckert, E. Eversheim, M. Müller, B. RedenzStormanns, U. Englert, P. Paetzold, Chem. Ber. 1995, 128, 1029-1035.

[26] J. H. Müssig, M. Thaler, R. D. Dewhurst, V. Paprocki, J. Seufert, J. D. Mattock, A. Vargas, H. Braunschweig, Angew. Chem. Int. Ed. 2019, 58, 4405-4409.

[27] J. H. Müssig, D. Prieschl, A. Deißenberger, R. D. Dewhurst, M. Dietz, J. O. C. Jiménez-Halla, A. Trumpp, S. R. Wang, C. Brunecker, A. Häfner A. Gärtner, T. Thiess, J. Böhnke, K. Radacki, R. Bertermann, T. B. Marder, H. Braunschweig, J. Am. Chem. Soc. 2018, 140, 13056-13063.

[28] Using the Pauling electronegativity of these elements $(\mathrm{Cl} 3.16, \mathrm{Br} 2.96$, I 2.66) from CRC Handbook of Chemistry and Physics, 84th Edition (D. R. Lide, ed.), 2003, CRC Press, Boca Raton, Florida.

[29] J. Böhnke, H. Braunschweig, P. Constantinidis, T. Dellermann, W. C. Ewing, I. Fischer, K. Hammond, F. Hupp, J. Mies, H.-C. Schmitt, A Vargas, J. Am. Chem. Soc. 2015, 137, 1766-1769.

[30] Y.-F. Lin, C.-W. Chiu, Chem. Lett. 2017, 46, 913-922.
[31] a) D. Franz, T. Szilvási, A. Pöthig, F. Deiser, S. Inoue, Chem. Eur. J. 2018, 24, 4283-4288; b) N. Arnold, H. Braunschweig, R. D. Dewhurst, F. Hupp, K. Radacki, A. Trumpp, Chem. Eur. J. 2016, 22, $13927-$ 13934; c) A. Weiss, M. C. Hodgson, P. D. W. Boyd, W. Siebert, P. J. Brothers, Chem. Eur. J. 2007, 13, 5982-5993.

[32] a) A. Widera, D. Vogler, H. Wadepohl, E. Kaifer, H.-J. Himmel, Angew. Chem. Int. Ed. 2018, 57, 11456-11459; b) R. Dinda, O. Ciobanu, H. Wadepohl, O. Hübner, R. Acharyya, H.-J. Himmel, Angew. Chem. Int. Ed. 2007, 46, 9110-9113.

[33] L. Kong, W. Lu, Y. Li, R. Ganguly, R. Kinjo, J. Am. Chem. Soc. 2016 138, 8623-8629.

[34] H. Braunschweig, A. Damme, R. D. Dewhurst, T. Kramer, T. Kupfer, K Radacki, E. Siedler, A. Trumpp, K. Wagner, C. Werner, J. Am. Chem. Soc. 2013, 135, 8702-8707

[35] a) A. Ault, J. Chem. Educ. 1970, 47, 812-818; b) E. D. Becker, High Resolution NMR, $3^{\text {rd }}$ Edition, 2000, Elsevier Inc

[36] NMR-spectroscopic analysis of the mother liquor remaining after crystallization of $\mathrm{B}_{2} \mathrm{Cl}_{4}\left(\mathrm{CAAC}^{\mathrm{Me}}\right)_{2}(76 \%$ isolated yield) suggested the presence of a second species (ca. $15 \%$ of total boron-containing produtcs), the ${ }^{1} \mathrm{H}$ NMR spectrum of which was reminiscent of $\left[\mathrm{B}_{2} \mathrm{Br}_{3}\left(\mathrm{CAAC} \mathrm{Me}_{2}\right] \mathrm{Br}\right.$. Although the identity of this second species could not be unequivocally confirmed, we suggest it may be $\left[\mathrm{B}_{2} \mathrm{Cl}_{3}\left(\mathrm{CAAC}^{\mathrm{Me}}\right)_{2}\right] \mathrm{Cl}$.

[37] Due to disorder in the central $B_{2} X_{3}$ unit the solid-state structures of $\left[\mathrm{B}_{2} \mathrm{Cl}_{3}(\mathrm{IDip})_{2}\right] \mathrm{BCl}_{4}$ and $\left[\mathrm{B}_{2} \mathrm{Br}_{3}\left(\mathrm{CAAC}{ }^{\mathrm{Me}}\right)_{2}\right] \mathrm{Br}$ cannot be discussed.

[38] Recent examples: a) Y. Katsuma, H. Asakawaa, M. Yamashita, Chem. Sci. 2018,9, 1301-1310; b) H. A. Sparkes, J. R. Smith, B. S. L. Collins, M. J. Hesse, E. L. Myers, V. K. Aggarwal, J. Am. Chem. Soc. 2017, 139, 9148-9151; c) J. Cid, A. Hermann, J. E. Radcliffe, L. D. Curless, H. Braunschweig, M. J. Ingleson, Organometallics 2018, 37, 1992-1998; d) N. Arnold, H. Braunschweig, A. Damme, R. D. Dewhurst, L. Pentecost, K. Radacki, S. Stellwag-Konertz, T. Thiess, A. Trumpp, A. Vargas, Chem. Commun. 2016, 52, 4898-4901.

[39] Y. Wang, B. Quillian, P. Wei, Y. Xie, C. S. Wannere, R. B. King, H. F. Schaefer, III, P. v. R. Schleyer, G. H. Robinson, J. Am. Chem. Soc. 2008, 130, 3298-3299.

[40] W. Van Doorne, A. W. Cordes, G. W. Hunt, Inorg. Chem. 1973, 12 1686-1689.

[41] C. Dai, S. M. Johnson, F. J. Lawlor, P. Lightfoot, T. B. Marder, N. C Norman, A. G. Orpen, N. L. Pickett, M. J. Quayle, C. R. Rice, Polyhedron 1998, 17, 4139-4143.

[42] P. Bissinger, H. Braunschweig, M. A. Celik, C. Claes, R. D. Dewhurst, S. Endres, H. Kelch, T. Kramer, I. Krummenacher, C. Schneider, Chem. Commun. 2015, 51, 15917-15920.

[43] H. Braunschweig, A. Damme, J. O. C. Jiménez-Halla, T. Kupfer, K Radacki, Angew. Chem. Int. Ed. 2012, 51, 6267-6271.

[44] H. Braunschweig, A. Damme, T. Kupfer, Chem. Commun. 2013, 49 , 2774-2776. 


\section{Entry for the Table of Contents}

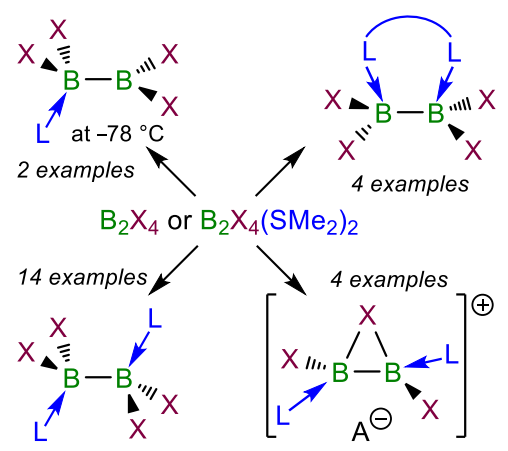

22 new tetrahalodiborane bis(base) adducts and two unstable mono(base) adducts were synthesized by the addition of carbenes, phosphines and isonitriles to highly sensitive $\mathrm{B}_{2} \mathrm{X}_{4}$ or by ligand exchange at stable $\mathrm{B}_{2} \mathrm{X}_{4}\left(\mathrm{SMe}_{2}\right)_{2}$ precursors. NMR-spectroscopic and crystallographic studies reveal a variety of structural motifs, from $\mathrm{sp}^{2}$-sp $\mathrm{sp}^{3}$-diboranes(5) and $\mathrm{sp}^{3}$ - $\mathrm{sp}^{3}$-diboranes(6) in staggered anti and gauche conformations to novel halide-bridged diboron cations. 